\title{
PRZEKŁADY
}

\author{
RUDOLF BERLINER
}

\section{WOLNOŚĆ W SZTUCE ŚREDNIOWIECZA}

Niezwykłym można by uznać stwierdzenie, że sztuka religijna Zachodu cieszyła się wielką wolnością w obrazowaniu wydarzeń historycznych i doktryny Kościoła w okresie średniowiecza. Jest tak być może, gdyż powszechnie przyjmuje się, iż sztuka średniowieczna była symboliczna. Jednak termin „symboliczny” sam z siebie nie załatwia problemu, który sformułować można stawiając następujące pytanie: „Jak to możliwe, że sztuka ośmiela się przedstawiać pewne tematy w taki sposób, że ich werbalne opisy są z historycznego, dogmatycznego, bądź intelektualnego punktu widzenia nie do zaakceptowania?". W poszukiwaniu odpowiedzi na to pytanie zamierzam wykazać, że wolność sztuki wynikała $\mathrm{z}$ teologicznych koncepcji jej roli w sferze religii. Przykłady nadzwyczajnej wolności udzielonej artystom posłużą do zilustrowania tego problemu.

W Ukrzyżowaniu na drzwiach płockich w Nowogrodzie, wykonanych około 1150 roku (il. 1), Chrystus, wciąż żywy na krzyżu, uwalnia prawą rękę, by wyciągnąć ją w kierunku swej matki ${ }^{1}$. To przedstawienie pozbawione jest historycznej podstawy, jeśli ma być interpretowane dosłownie. Ale w swym zamyśle nie miało być interpretowane dosłownie; gest ów miał wizualizować intensyfikację agonii Chrystusa, gdy spoglądał On na zasmuconą matkę oraz nadawać religijne znaczenie jej boleści. To biskup Aleksander z Płocka, który zamówił drzwi, albo też arcybiskup Wichmann z Magdeburga, któremu być może powierzono nadzór nad szczegółami ich wykonania, tak właśnie zinterpretował tę „stację” Pasji Chrystusa. Tak jak naturalnym było dla biskupa udzielenie wsparcia werbalnego

1 A. Goldschmidt, Die Bronzetüren von Nowgorod, Marburg 1932, s. 16, 20, il. 55. Goldschmidt poszukiwał wyjaśnienia tego gestu w analogicznym motywie w scenach złożenia do grobu. Badacz ilustruje jednak fakt domniemany. Nawet jeśli Goldschmidt miał rację, problem wciąż pozostaje aktualny. Doniosłość tego gestu zauważona została przez Fr. Adelunga, Die Kurssun'schen Türen, Berlin 1823, s. 45 oraz przez A. Brykcsijnski'ego (cytowany przez J. Leveta w: Revue de l'Art Chrétien, XLVI, 1903, s. 140). W.L. Hildburgh (w: „Archaeologia”, 81, 1931, s. 56) podążał za Goldschmidtem w wyjaśnieniu znaczenia tego gestu, którego przedstawienie stanowiło dlań większą zagadkę niż dla Goldschmidta. 
jego słuchaczom lub czytelnikom w zrozumieniu wagi wydarzeń związanych z Pasją, tak też nie zgłaszał on sprzeciwu co do udzielenia podobnego wsparcia widzom - wsparcia będącego rezultatem kreatywnej mocy artysty; wsparcia w rozumieniu poprzez zmysł wzroku; wsparcia, od którego oczekiwano reakcji emocjonalnej, a nie intelektualnej.

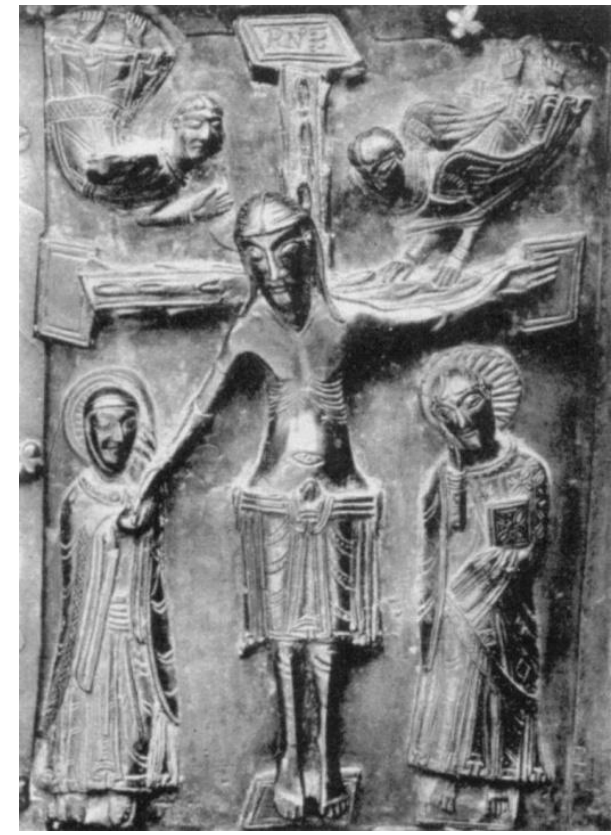

1. Ukrzyżowanie, Niemcy, ok. 1152, drzwi płockie, Katedra, Nowogród, Rosja

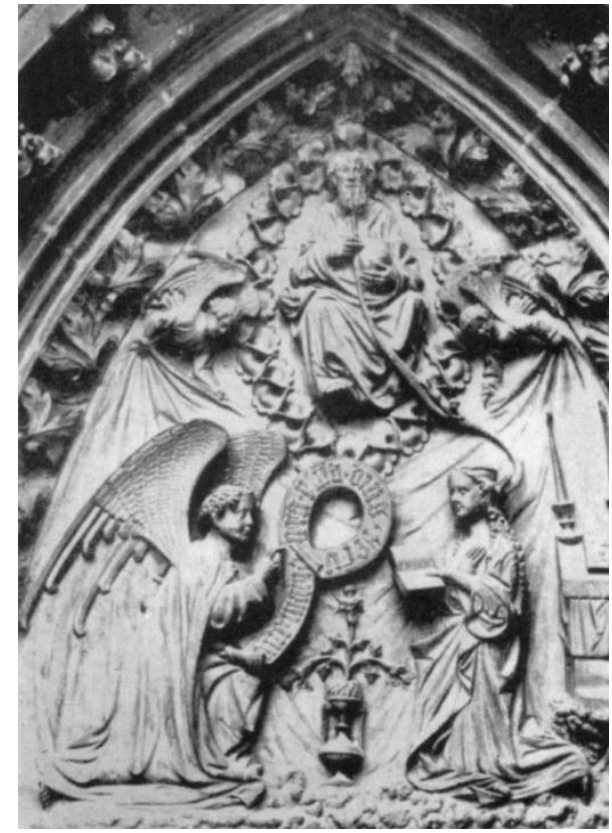

2. Zwiastowanie, Niemcy, ok. 1435, kaplica Maryjna, Würzburg

Wiele przedstawień ukazuje Chrystusa stojącego w sarkofagu, a jego ciało całkowicie lub częściowo in rigore mortis, lecz czynnie stojące, a więc żywe (il. 3). Inne ukazują martwe już ciało, z wciąż żywą głową Chrystusa umierającego na krzyżu (il. 6)2 lub na łonie Dziewicy (il. 7). Zwłoki mogą mieć żywe jeszcze oczy (il. 8), żywe zaś ciało oczy osoby zmarłej (il. 9). Istnieją pewne typy prezentacji Chrystusa martwego, jednak nie pozbawionego życia. Bycie żywym i martwym jednocześnie nie ma żadnego racjonalnego sensu. Jednak w śmierci Chrystusa naturalny porządek

2 Il. 6 reprodukowana jest tu za K. Loefflerem, Schwäbische Buchmaleriei in romanischer Zeit, Augsburg 1928, il. 17. Inskrypcje odnoszą się do śmierci Chrystusa. Najbardziej wymowna brzmi: „Przecierpiawszy na krzyżu, zbawię teraz Adama” itd. - il. 7 (Schreiber, 973); Pieta nie jest przedstawieniem „nieprawdziwym”. W nowożytnej egzegezie katolickiej scena ta pojawia się w Wulgacie, zob.: Iob 19, v. 27: „Nadzieja spoczęła na moich kolanach”. Il. 8 reprodukowana za C. Dodgsonem, English woodcuts, 1936, nr 13. 


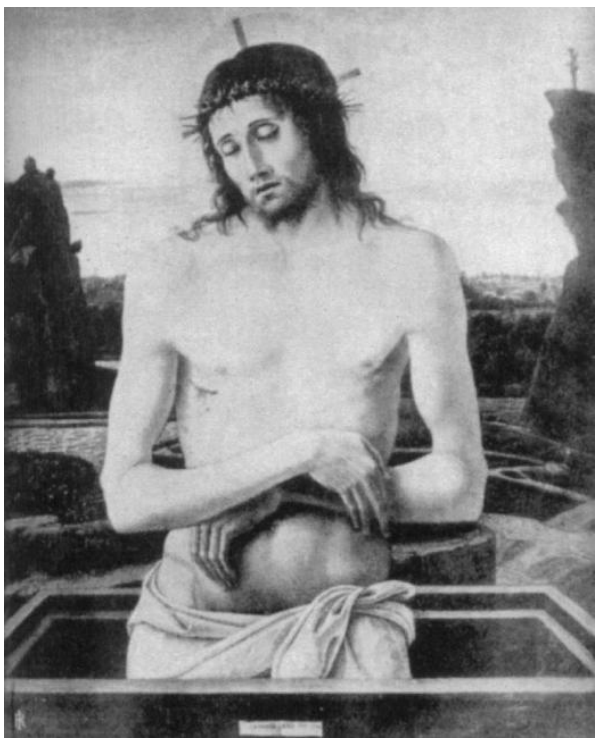

3. Naśladowca Giovanniego Bellini, Maż boleści - Chrystus w sarkofagu, ok. 1500, Muzeum Poldi Pezzoli, Mediolan

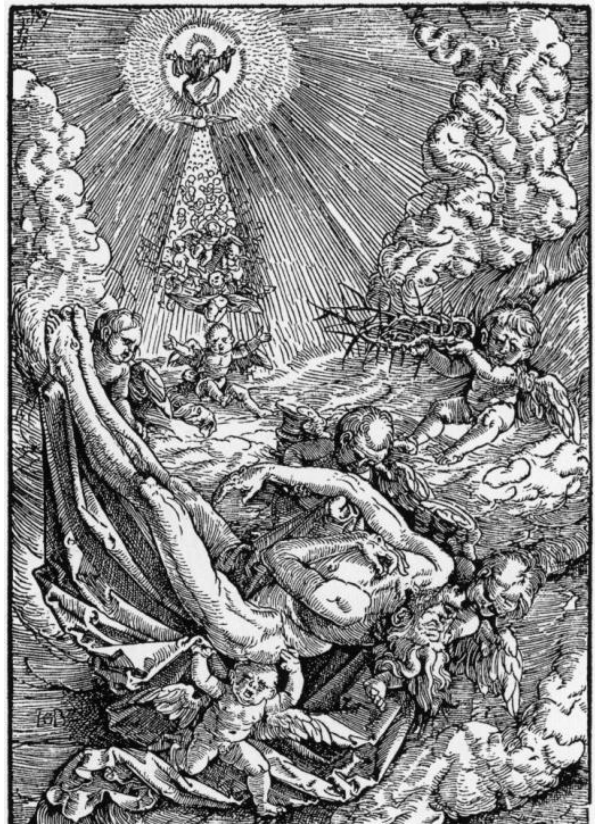

5. Hans Baldung Grien, Ofiarowanie, drzeworyt, ok. 1515

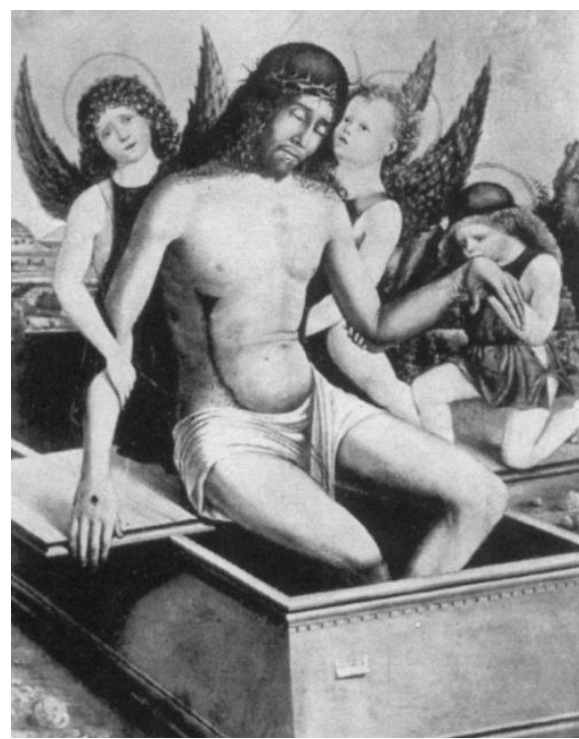

4. Antonello da Saliba, Złożenie do grobu, ok. 1490, Pałac Dożów Wenecja

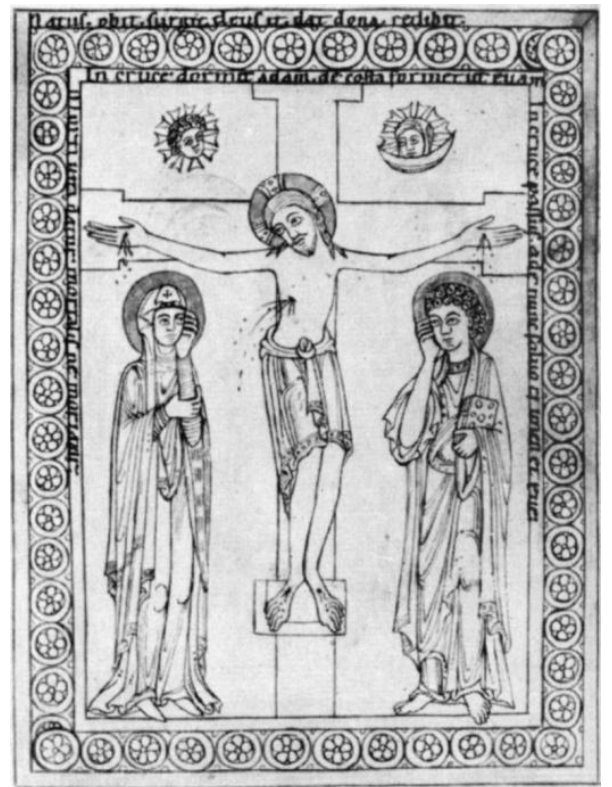

6. Ukrzyżowanie, rysunek piórkiem, Niemcy, ok. 1125, Württembergische Landesbibliothek, Stuttgart 
rzeczy został zastąpiony życiem nadprzyrodzonym. Chrystus cierpiał qua homo. Zmarł jako człowiek, a Jego dusza opuściła Go. Jednak qua deus Jego bycie częścią Trójcy nigdy nie zostało naruszone. By więc pokazać Chrystusa triumfującego nad śmiercią, mimo że jego ciało było niezaprzeczalnie już martwe, ukazywano go żywym na przekór wszelkim znakom śmierci. Nigdy nie zamierzano jednak sugerować, „iż Zbawiciel powrócił do życia na krótki okres pomiędzy ukrzyżowaniem a złożeniem do grobu"3. Taka, całkowicie fantastyczna interpretacja, dowodzi tego, jak trudnym jest zrozumienie intencji irracjonalistycznej sztuki poprzez podejście racjonalne. Rozum jest raczej bezradny wobec dzieł sztuki, których opis werbalny jest nieadekwatnym środkiem komunikacji ich treści.

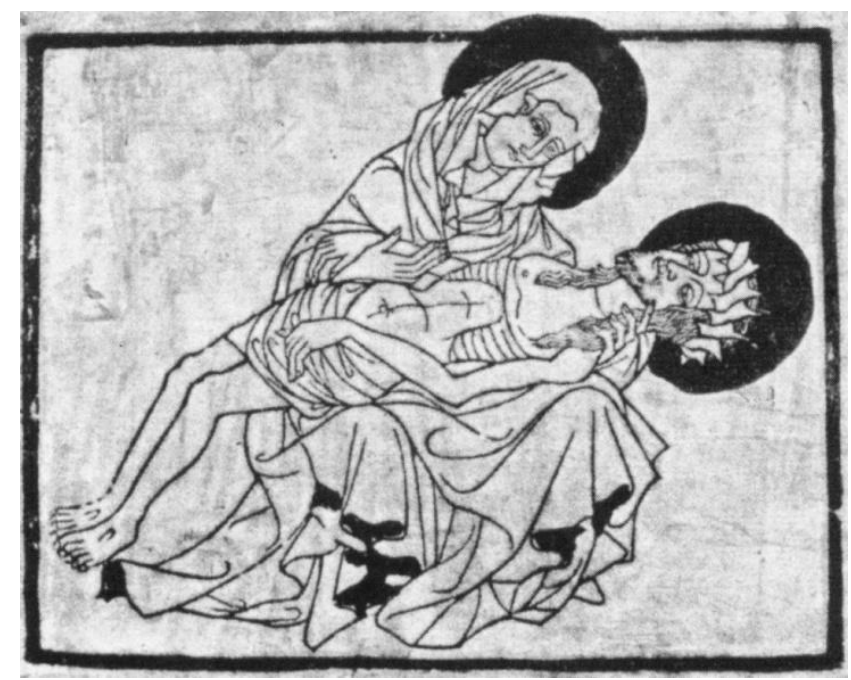

7. Pieta, drzeworyt, Austria, ok. 1410

Antonello da Sailba (il. 4) wiedział, rzecz jasna, że Chrystus nie był niesiony do grobu przez anioły. Jednak anioły były niezbędne, by pokazać, że on jest Bogiem. Hans Baldung Grien wiedział, że martwe ciało Chrystusa nie wstąpiło do Nieba (il. 5). Chciał on jednak zintensyfikować efekt emocjonalny poprzez skontrastowanie całkowicie ludzkiego rozkładu z majestatem Królestwa Niebieskiego.

${ }^{3}$ K. Künstle, Ikonographie der Christlichen Kunst, T.1, Fryburg Bryzgowijski 1928, s. 486. Również Franz Bock nie był w stanie wyjaśnić takiego przedstawienia w sposób satysfakcjonujący w: Jarhbuch der K.K. Central-Commission zur Erforschung der Baudenkmale, III, 1859, s. 113. Najbliższe moim interpretacjom są Anna Jameson oraz Lady Eastlake, The History of Our Lord, Londyn 1864, T. II, s. 362. Sądzę jednak, iż związek $\mathrm{z}$ sakramentem Eucharystii pojawił się dopiero u schyłku XIV wieku. 


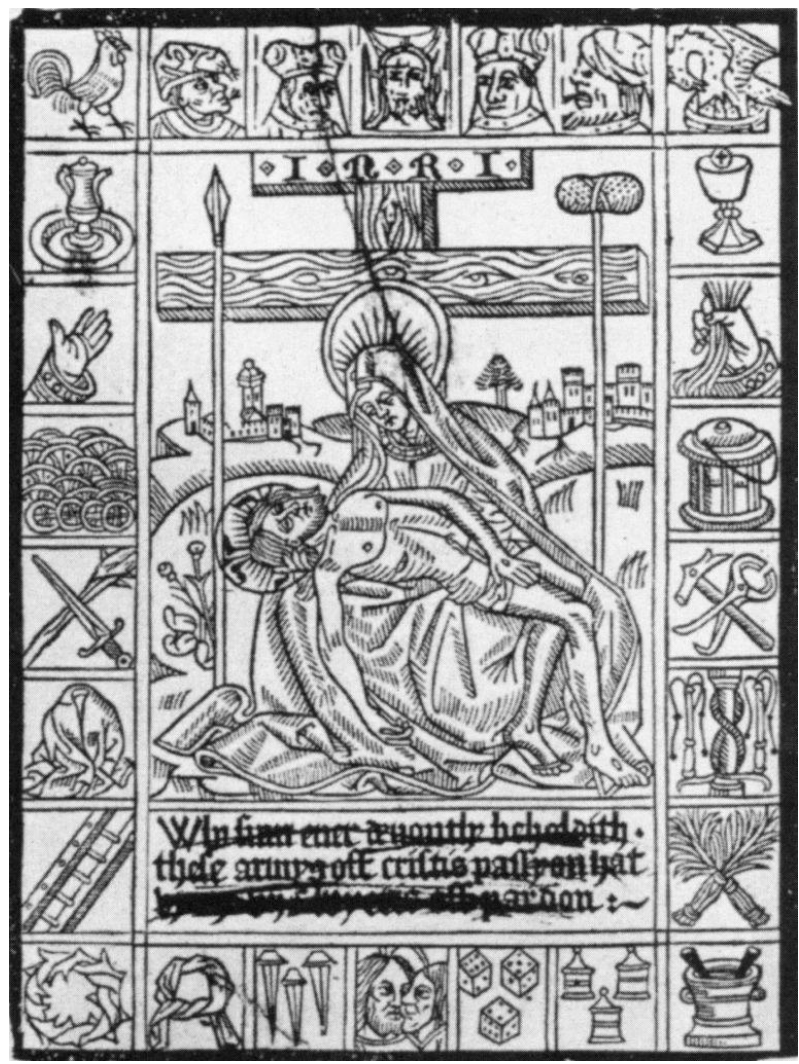

8. Pieta jako element Arma Christi, Anglia, ok. 1490

Innej, najbardziej chyba uderzającej ilustracji tego problemu, dostarczają przedstawienia ukazujące pewną sprzeczność $\mathrm{w}$ jednym z najbardziej fundamentalnych dogmatów - Wcieleniu Syna Bożego, w którym to Dzieciątko zstępuje z Niebios do Dziewicy. W ten sposób Jej udział w poczęciu był zanegowany. Jednakże ani artyści, ani bardziej tolerancyjni księża nie chcieli przecież popaść w walentyniańską herezję $e^{4}$. Chętnie przyznaliby więc, iż interpretacja przedstawienia powinna odbiegać od jego wizualnej wymowy. Zastanawialiby się zapewne, dlaczego właściwie należy oczekiwać, iż przedstawienie i jego sens muszą być wyraźnie i rzeczowo ze sobą skorelowane. $\mathrm{Z}$ ich punktu widzenia coś może wydać się fałszem, gdy ubrane jest to w słowa, lecz przestaje nim być, gdy postrzegane jest wzrokiem i kontemplowane emocjonalnie; a więc przedmiot naszej percepcji i jego intelektualna interpretacja nie muszą być skorelowane w sposób oczywisty.

${ }^{4}$ K. Künstle, op. cit., s. 340. 


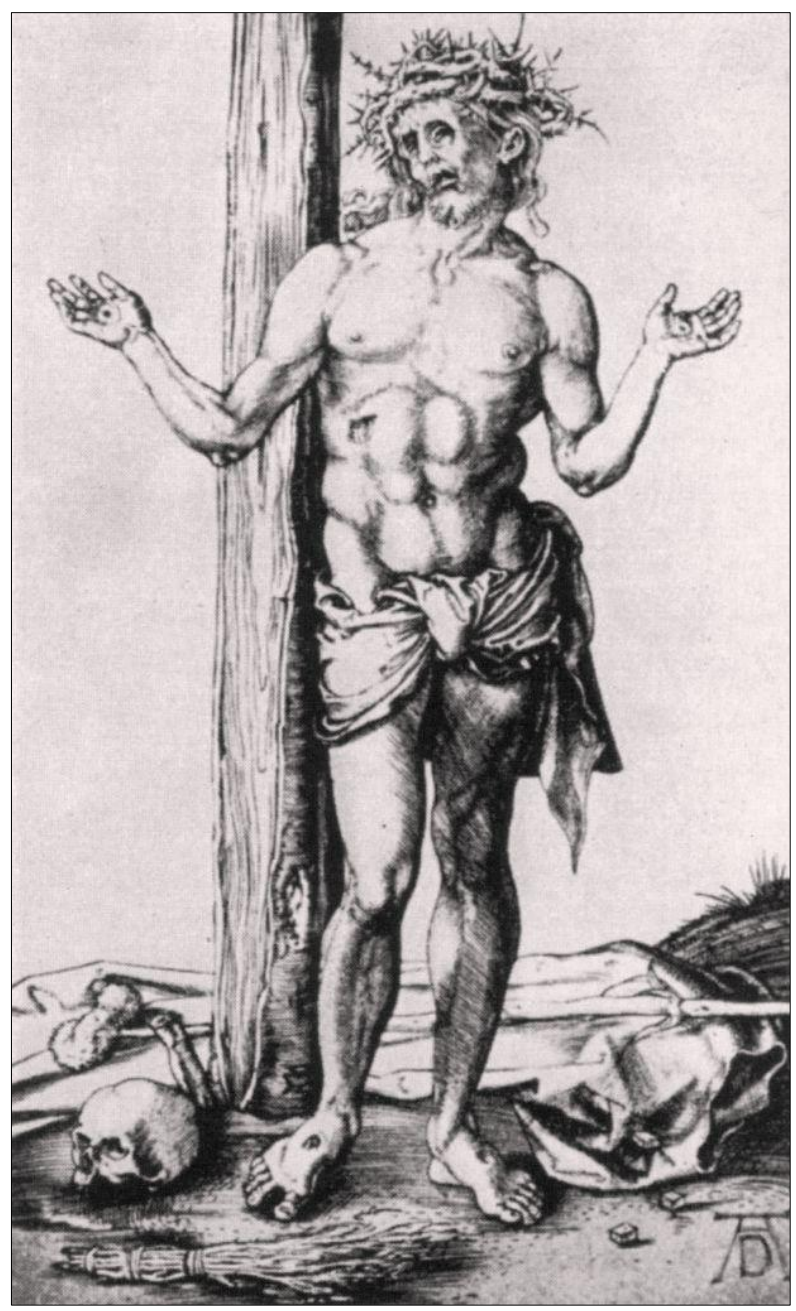

9. Albrecht Dürer, Mąż boleści - Chrystus pod krzyżem, rycina, ok. 1500

Kontrowersja ikonoklastyczna z VIII wieku uwypukliła znaczenie pytania, czy materia może wyrażać duchowość za pośrednictwem materialnych przedstawień. Libri Carolini, zawierające idee Karola Wielkiego i grona jego doradców, rozwiązały ten problem poprzez zaprzeczenie jego istnienia ${ }^{5}$. Chodziło dokładnie o rozstrzygnięcie, czy obrazy posiadały zdolność do ujawniania wiedzy o Bogu ponad mocą słów. Jedna z najbardziej znanych sentencji (II, 22): „człowiek może zostać zbawiony bez oglądania obrazów, lecz nie może bez znajomości Boga” - omija problem.

${ }^{5}$ E.H. Bastgen (red.), Monumenta Germaniae, Concilia, II, wyd. uzup., 1924. 
Libri ograniczają cel obrazu prawie całkowicie do stymulowania pamięci poprzez jego zawartość. Przedstawianie fenomenów duchowych leży poza mocą obrazu, bowiem to słowa, a nie obrazy są duchowymi nauczycielami. Odmówiono dziełu sztuki nawet konkretnego, jednostkowego wpływu na emocje. W sprzeczności z tym stoi przyznanie obrazom oddziaływania czysto estetycznego, wartości dekoracyjnej oraz zróżnicowanych jakości artystycznych (IV, 27), co potwierdza fakt, iż problem nie został zgłębiony w pełni.

Autorzy Libri nie zadali sobie trudu przeanalizowania szczególnych, ekspresyjnych właściwości sztuki, których istnienie sugerowali uczestnicy sporów ikonoklastycznych w późnej starożytności i wczesnym Bizancjum $^{6}$. Odmawiali przyznania sztuce powszechnie akceptowanej już cechy odkrywczości - jej zdolności do przedstawiania niewidzialnego świata. Cecha ta zyskała bezwarunkową akceptację w wypowiedziach retora Diona Chryzostoma (ok. 100 n.e.) oraz pogańskiego filozofa Porfiriusza (ok. 260 n.e.), którzy stwierdzili, że to, co z natury rzeczy niewidzialne, można uczynić postrzegalnym poprzez sztukę7. Uznanie to zakładało, że konstatowana u poetów od starożytności boska inspiracja powinna być przypisywana również artystom. Retorzy byli pierwszymi, którzy dokonali tego publicznie. Uczynił to Dion, a Kalistrat (III wiek n.e.) stwierdził jednoznacznie: „Dzieła sztuki to także objawienia o boskiej inspiracji”. Ujawniają boskie, jak również inne niewidzialne zjawiska, nadając im formę. Sztuka czyni swe tematy prawdziwymi, tworząc sama „strukturę rzeczywistości”".

Uczynić dostrzegalnym to cel sztuki, powiadał Filostrat Starszy (zm. ok. 245), a dostrzegalność niewidzialnego osiągana jest przez wyobraźnię, to jest, przez umiejętność tworzenia odpowiednio ekspresywnych form ${ }^{10}$.

6 J. Geffcken, „Archiv für Religionswissenschaft”, XIX, 1916/19, s. 286ff. Bo de Borries, Quid veteres Philosophi de idolatria senserint, Getynga 1918.

7 Dion Chryzostom: Olympikus, 59. B. Schweitzer, Neue Heidelberger Jahrbücher, 1925, s. 119. Porfiriusz: J. Bidez, Vie de Porphyre, Gandawa 1913, p.I+. J. Geffcken, op. cit. s. 306 i n.

${ }^{8}$ Dion, Olympikus, 59, Kalistrat: Statue, 2. B. Schweitzer, op. cit., s. 121, 81.

${ }^{9}$ Kalistrat, Statuae 10 (zwrócić uwagę na argumentację) oraz 2.

10 Im. II, 14; Apollonius, VI, 19 (por. Schweitzer, op. cit., s. 110) Chociaż Schweitzer ustąpił („Philologus” 89, 1934, s. 297), wierzę, że jego pierwsza interpretacja frazy z Apolloniusa była jednak lepsza niż E. Birmelina, („Philologus” 88, 1933, s. 395 i n.). M.W. Bundy, The theory of Imagination in Classical and Mediaeval Thought, University of Illinois, 1927, s. 114 i n.; Filostrat Młodszy, Obrazy, Wstęp. Ani Filostraci w Obrazach ani Kalistrat nie pisali jako filozofowie sztuki. Ich twórczość określić można jako tworzenie modeli mówienia o i patrzenia na dzieła sztuki. Zdaje mi się, że raczej dość konsekwentnie powtarzali oni punkt widzenia współczesnych im artystów aniżeli filozofów. Filostrat Starszy podkreślał we Wstępie rolę swojej przyjaźni z malarzem Aristodemusem. Wyjaśniając 
Istotne dla niego było oczywiście realistyczne przedstawienie, korespondujące $\mathrm{z}$ rzeczywistością, ale tylko do punktu, w którym rzeczywistość ta zaadaptowana była do specyficznych wymogów artystycznej formy ${ }^{11}$. Ten, kto udziela aprobaty temu, co zgodne jest z mimesis, z imitacją widzialnej natury, chwali zwykłe banały (I,9). Filostrat wykazywał niewielkie zainteresowanie zwykłym efektem realistycznym, którego celem jest naturalistyczna iluzja (I, 23). Istotna treść osiągać należy za pośrednictwem formy widzialnej (II, 13). Sztuka sięga poza mimesis poprzez wizualizację wewnętrznego znaczenia, właściwego tematowi (I,9)12. Ważniejsza od efektu czysto wizualnego, choćby był on sam w sobie piękny, jest zdolność sztuki do wyrażania swej wagi w sensie innym niż estetyczny. Filostrat mógłby być oryginalnym autorem frazy biskupa Asteriusza z Amazji (330-410): „Podziwiam artystów za poświęcanie większej uwagi harmonii duchowego wyrazu, niż [jedynie] kolorów”13.

Starożytni Grecy zdawali się, co do zasady, nie akceptować czysto hedonistycznej koncepcji sztuki, a raczej oczekiwali od niej, poza wszystkim innym, odwołania do umysłu. Wykazywali oni ogromne zainteresowanie fizjonomiką w najszerszym znaczeniu tego słowa oraz ekspresywnymi właściwościami formy ${ }^{14}$, od której oczekiwali czegoś więcej, aniżeli tylko piękna.

To uświadomienie sobie rzeczywistej obecności boga i jego natychmiastowe doświadczenie, nie zaś czysto estetyczne jakości, przenosiły, zdaniem Diona, widza podziwiającego Zeusa Olimpijskiego ponad wszelkie ludzkie cierpienie. Dion nie był w żadnym razie zwolennikiem kon-

dzieła sztuki, żaden z tych trzech filozofów nie odnosił się do abstrakcyjnych zasad filozoficznych, miast tego wszyscy oni silili się na nauczanie, jak formy te mają być rozumiane, by uchwycić intencje artysty, które, rzecz jasna, identyfikowali z własnymi pomysłami. (Odkąd napisałem te słowa Karl Lehmann-Hartleben opublikował doskonały artykuł na temat Obrazów Filostrata Starszego, w: „The Art Bulletin”, 23, 1941, s. 16 i n., por. s. 41 i n.) Wierzyli oni, że mimesis i phantasia musiały wnieść swój wkład, jeśli obraz miał być satysfakcjonujący. Phantasia będzie dążyć do uczynienia niewidzialnego postrzegalnym, aż przedstawiona zostanie cała Istota tematu (Filostrat Młodszy, Wstęp). Bundy traktował historię terminów mimesis oraz phantasia szczegółowo, ale nie zwracał zbytniej uwagi na konkretny artystyczny problem czynienia rzeczy postrzegalnymi, który odnosi się do realizacji koncepcji fantazji jak również do imitacji widzialnego. Zdaje się on interpretować uświadomienie, itp. jako proces wyłącznie mentalny.

11 Zob. przykłady Im. I, 12; II, 1.

12 C.O. Kuelpe, Anfänge psychologischer Aesthetik bei den Griechen, (w:) Psycholophische Abhandlungen, Max Heinze (...) gewidmet, Berlin 1906, s. 121.

13 Migne, Patrologia graeca, XL, Hom XII, kol. 337.

14 Por. T. Brit, Laienurteil über bildende Kunst bei den Alten, Marburg 1902, s. 23 i n.; K. Borinski, Die Antike in Poetik und Kunsttheorie, Lipsk 1914, T. 1, s. 94, poczynił kilka uwag o klasycznym zainteresowaniu fizjonomiką i jej ewentualnym reperkusjom w erze chrześcijańskiej. 
cepcji idolatrii, wedle której bóg żyje w swym obrazie, lecz przydawał temu dziełu sztuki moc odkrywania absolutnej prawdy przez nie-intelektualne, bierne poznanie. Damasciusz (ok. 480 n.e.) „począł pocić się ze zdumienia i emocji” zobaczywszy posąg Afrodyty. Z zachwytu nie mógł niemalże oderwać się od dzieła, „takie wrażenie zrobiło na nim piękno zawarte w nim przez artystę"15. Ciąg dalszy komentarza pokazuje jednak, że piękno rozumiano jako umiejętność ukazania duszy bogini poprzez nadanie jej siły, wigoru, zdolności do obrony, a przez to stworzenie wrażenia, iż powraca ona ze zwycięskiej walki. Porfiriusz nauczał, że takie objawienia boskości poprzez sztukę są względne i mogą być doświadczone jedynie przez tych, na których oddziałała inspiracja bądź wiedza ${ }^{16}$. Libanios natomiast (prawdopodobnie w 361 r. n.e.) uznał za rzecz oczywistą fakt, iż zwykła kontemplacja obrazów bogów uczynić może człowieka mądrym ${ }^{17}$.

Rzecz jasna, jak długo trwał Antyk, pogląd głoszący, że sztuka pozbawiona jest głębszego znaczenia, znajdował swoich zwolenników. Sztuka figuratywna zaczęła jednak zyskiwać znaczenie autonomicznej metody pozyskiwania wiedzy, w żaden inny sposób nieosiągalnej. Zwycięstwo stało się wyraźne, gdy w $\mathrm{V}$ wieku pogański filozof zaakceptował teorię, wedle której wielkim artystom przypisywać należy inspirację, a zatem coś więcej niż ludzkie zdolności ${ }^{18}$. Artyści, ci „prymitywni rzemieślnicy, którzy pracują na chleb", wygrali z filozofami osłabiwszy ich przy pomocy retorów ${ }^{19}$ oraz - możliwe - chrześcijańskich teologów.

Istnieją dwie grupy ludzi myślących lub mówiących o sztuce: ci, którzy ją uprawiają i czynią ją osobistym wyrazem swej witalności i stosunku do świata, oraz ci, którzy są zwyczajnie wrażliwi na twórczość tej pierwszej grupy. Nie jest z pewnością zbiegiem okoliczności, że najwcześniejsze przyznanie sztuce zdolności obrazowania wewnętrznego życia człowieka wyszło z ust byłego rzeźbiarza, Sokratesa ${ }^{20}$. Koncepcja, wedle której sztuka ufundowała swoje kreacje w języku form, i że poprzez odpowiednie przedstawienie zrealizować można nie tylko zewnętrzny wy-

15 R. Asmus, Das Leben des Philosophen Isodoros, Lipsk 1911, s. 53.

16 Euzebiusz, Praeparatio Evangelica, III, 7; PG XXI, kol. 180. „(...) ci, których uczono czerpać z obrazów, tak jakby były księgami, wiedzą bogów”. Co zaskakujące, Edward Stillingfleet zinterpretował to zdanie jako nadające obrazom status biblii pauperum, A Discourse Concernig the Idolatry Practiced in the Church of Rome, trzecie wydanie, Londyn 1672.

${ }_{17}$ Or. 64, pro saltatoribus, wyd. Foerster IV, 495, par. 116.

${ }^{18}$ Był to najpewniej Izodor lub Damascjusz. R. Asmus, op. cit., s. 74.

19 Britt, op. cit., s. 28, twierdzi w innym kontekście, iż teksty artystów mogły także wpływać na retorów.

${ }^{20}$ Ksenofont, Memorabilia, III, 10. Zob. Britt, op. cit., s. 15; Kuelpe, op. cit., s. 109. 
gląd, ale również esencję i naturę tematu, musiała rozwinąć się w pracowniach artystycznych ${ }^{21}$. Do logicznych następstw rzeczy należało to, że artyści w pewnym momencie zmuszeni byli lansować pogląd o wyższości artystycznych form wyrazu nad zwykłym kopiowaniem rzeczywistości ${ }^{22}$. Ich powołaniem były wrażenia wizualne i celem nadrzędnym stało się dla nich, jak tylko samoświadomość rozbudziła się w ich kręgu, by występować jako obrońcy tego twierdzenia poprzez podkreślanie ich pozytywnych dokonań - zdolności kreowania nastroju, czynienia widzialnym w inny sposób niedostrzegalnego oraz nadawania formy „rzeczom nieznanym”. Dla przykładu, gdy filozofowie podkreślali fakt, iż centaury są anatomicznie niemożliwe, artyści odpierali, że mogli mimo to uczynić je wizualnie przekonującymi ${ }^{23}$. Zarówno oni, jak i ich następcy mogli interpretować dzieło sztuki jako autonomiczne podejście do wiedzy poprzez tworzenie właściwych form wizualnych, odnoszących się do emocji, w przeciwieństwie do wszelkich innych dróg angażujących intelekt.

Ci spośród teologów chrześcijańskich, którzy skłaniali się ku pozytywnej relacji między religią i sztuką, mogli zaakceptować tę teorię nawet jeśli nie zgadzali się ze wszystkimi argumentami, które były wysuwane w celu jej potwierdzenia. Nie mogli na przykład zaakceptować, rzecz jasna, bezkrytycznego przypisania artystom szczególnych, duchowych darów, jako przynależnych ich profesji; mogli natomiast, po roku 600, uczynić to w indywidualnych przypadkach, jak choćby świętych, którzy uznawani byli za chrześcijańskich arcyartystów, takich jak św. Łukasz czy Nikodem ${ }^{24}$. Akceptowali oni pojmowanie sztuki jako odrębnego i niezastąpionego sposobu zbliżenia się do Boga, lub przynajmniej jako najbardziej efektywnej drogi dotarcia do ludzkiej duszy. Grzegorz z Nyssy (druga połowa IV wieku) relacjonował, iż nie potrafił patrzeć na żaden z obrazów przedstawiających Ofiarę Abrahama, by nie wzruszyć się do łez ${ }^{25}$. Biskup Bazyli z Ankary skomentował te słowa w roku 787, podczas Soboru Nicejskiego II, w sposób rozstrzygający, stwierdzając, że malowa-

${ }^{21}$ Dion Chryzostom, IV, 86. „Nie potrafią nadać obrazom słów, ale potrafią ucieleśnić je we właściwych figurach, odpowiednich do ukazania ich natury...”.

22 Pewne uwagi na temat tych zmian poczynił P. Wolters, w: Münchner Jahrbuch der bildenden Kunst, 1934, s. 10 i n., oraz przez Schweitzera w: „Philologus”, 89, s. 291.

23 Zob. np. Lukrecjusz, De rerum natura, V, 578 i n., Lukian, Zeuxis 3, Filostrat, Obrazy II,2. Temat ten powtarza się u Cennino Cenniniego w Libro dell'arte, rozdział I, ok. 1400.

${ }^{24}$ Świadectwo z około 1300 roku mówi o panującym przekonaniu, że u zarania Kościoła prototypy wszystkich obrazów zostały stworzone przez Świętych, a te które przybyły z Bizancjum otaczane były wielką czcią. C.E. Narducci, Prediche inediti del B. Giordano Rivalto, Bologna, 1867, s. 170, 17.

25 Oratio de deitate filii et spiritui sancti, Patrologia Graeca, XLVI, kol. 572. 
na wersja tej sceny wywołała u Grzegorza efekt, którego biblijny opis tej samej sceny nie wywołał 26 . Współczesny Grzegorzowi Bazyli Wielki ochoczo przyznał, że malowane przedstawienia robią większe wrażenie niż przekaz słowny27.

Za podstawową zasadę chrześcijaństwa uznawano fakt, iż nie polega ono na teoretycznej akceptacji dogmatów i faktów („po części tylko poznajemy”), lecz bazuje na wierze, nadziei i miłości, z których miłość jest najważniejsza (I Kor 13,13). Chrześcijaninem nie jest ten, który zna nauki Chrystusa, lecz ten, który nimi żyje. Zachowanie powinno być zatem uwarunkowane pragnieniem naśladowania - upodobnienia się do Chrystusa i Świętych. Obrazy mogą ułatwić ten wysiłek, jako że konkretyzują cechy sportretowanych osób. Zgadzają się z tym tak chrześcijanie, jak i poganie. Zdolność portretu do czynienia „naturalnej osobowości podmiotu czysto i wyraźnie dostrzegalną”, jak mawiali poganie późnej starożytności ${ }^{28}$, mogła uzyskać szczególne religijne znaczenie dla chrześcijanina. Autentyczne portrety Chrystusa, zarówno dzieła ludzkie jak i rezultaty cudów, były dlań prawowitym źródłem wiedzy o ludzkiej naturze Chrystusa $^{29}$.

Związek Boga i człowieka został spełniony poprzez życie Chrystusa. To wskazuje na fundamentalną różnicę pomiędzy całą pogańską i chrześcijańską sztuką. Jeśli w sferze klasycznej religii okazjonalnie pojawiała się wiara $\mathrm{w}$ widzialne objawienie się boga, to był to zaledwie krótkotrwały przebłysk nadprzyrodzonego w ziemskim świecie. Oba te światy pozostawały w swej istocie od siebie oddzielone. Odkąd jednak Chrystus przeżył całe ludzkie życie, od narodzin do śmierci, możliwym było przedstawianie Go w ludzkiej postaci, która sama przecież została stworzona „na boskie podobieństwo”30. Zatem starożytny problem, jak człowiek mógł założyć prawo do wyobrażania boskości na swoje podobieństwo, został rozwiązany. W przedstawieniach Chrystusa ukazujących Go w ludzkiej postaci odnaleźć można więc nadprzyrodzoną prawdę, o ile przedstawienie będzie do Niego podobne, jako że objawił się On w doczesnej rzeczy-

${ }^{26}$ Mansi, Conciliorum collectio, XIII, kol. 10.

${ }^{27}$ Homiliae in Barlaam martyrem, Patrologia Graeca, XXXI, kol. 490.

${ }^{28}$ Asmus, Isidorus, s. 54.

29 [Protestancką] sztandarową pozycją na ten temat jest: Ernst von Dobschuetz, Christusbilder, Lipsk 1899. Podąża ona innym tokiem rozumowania niż niniejsza publikacja. Twierdzenie zawarte na stronach $280-281$ jest, w mej opinii, godne pożałowania. Rzecz jasna, nie ma pewności, w jakim stopniu laicy akceptują nauki Kościoła. Jednak zaprzeczanie bez choćby próby dowiedzenia, nie prowadzi do rozwiązania tej kwestii.

30 Zob. początek teorii K. Holla, Sitzungberichte der K. Preussischen Akademie der Wissenschaften, 1916, s. 876 i n. większość teologów cytowała Jana z Damaszku jako autorytet. O ile mi wiadomo, był on najczęściej cytowanym autorytetem w kwestii obrazów. 
wistości. Prawdziwy portret Chrystusa powinien pozwolić na objęcie umysłem czegoś z Jego niewidzialnej boskości. Święty Paweł napisał, że poprzez twarz Chrystusa przekazano człowiekowi wiedzę o Bożej chwale (II Kor 4,6), sam Chrystus zaś jest „obrazem niewidzialnego Boga” (Kol 1,15; conf. Hbr 1,3) w stopniu daleko przewyższającym zwykłą ludzkość.

Metafizyczna relacja pomiędzy „przedmiotem” i „obrazem” jest jednym z podstawowych założeń chrześcijańskiej koncepcji wszechświata. Jeśli przyjąć, że, zgodnie z naturą ludzkiego umysłu, nadprzyrodzone jest postrzegalne tylko przez widzialne obrazy, to obraz artystyczny staje się niezbędną pomocą w celu osiągnięcia wiedzy, a działalność artystyczna uznana może być za fundamentalną siłę. Jan z Damaszku (ok. 675-749) dobitnie sformułował tę teorię: „Jeśli z miłości do człowieka bezkształtne otrzymuje kształt $\mathrm{w}$ zgodzie $\mathrm{z}$ naturą, dlaczego nie mielibyśmy $\mathrm{w}$ obrazach rysować tego, co stało się dla nas jasne poprzez kształt, w sposób nam właściwy, celem stymulowania pamięci i pobudzania do naśladowania rzeczy, które mogą być przedstawiane?”31. Nie może być jednak dowolności; przedmiot i obraz musi łączyć podobieństwo ${ }^{32}$. Dopiero wówczas aktualna rzeczywistość i pozbawiony życia obraz stają się zgodne co do formy, a sam obraz przekazuje pewną wiedzę o istocie portretowanego. To nadaje obrazowi pewną siłę witalną, którą w rzeczywistości ma lub miał portretowany w swym władaniu. Siła ta przekazywana jest przez same cechy formy artystycznej - koncepcja ta bazuje raczej na platońskiej teorii percepcji, aniżeli na sugestii działania magicznego, czego nie uniknął nawet Plotyn w swoim pojmowaniu wszechobejmujących powiązań, które tworzą moc w obrazie boga ${ }^{33}$.

W opinii obrońców obrazów wzbogacenie życia duchowego oraz silne emocje, wzniecone w duszy poprzez wizualne przedstawienia, prowadzą do dążenia do naśladowania ${ }^{34}$. Wierzono, że percepcja ma sięgnąć poza emocje i stać się stymulantem woli. Uważano, że obrazy miały uczynić człowieka lepszym; czynne uświęcenie jest pierwowzorem współczesnego pasywnego uczucia „uskrzydlenia”. Kontemplacja obrazów powinna doprowadzić do faktycznego czynienia dobra i woli wytrwania w cierpieniu. Toteż patriarcha Germanus z Konstantynopola zdefiniował około 720 ro-

${ }^{31} \mathrm{PG}$, XCIV, De imaginibus oratio I, Główny passus w kol. 1260, podobne zdania w kol. 1241 i innych komentarzach Jana do fundamentalnych fragmentów z Dionizego Areopagity, De divinis nominibus I,4 (PG III, kol. 592). zob. przypis 43.

32 Zob. św. Jan Chryzostom, In epustulam ad Colossos hom. III PG LXII, kol. 318: „Obraz tylko wówczas jest obrazem, jeśli jest aktualny również wśród nas [ludzi] - gdy jest podobny, przedstawia charakterystyczne cechy i wizerunek [przedstawianego]...”.

33 Plotyn, Enneady, IV 3, 11; Geffken, op. cit., s. 304. Odpowiednie platońskie idee znaleźć można w Fajdrosie i Państwie w interpretacji Waltera Patera w: Marius the Epicurean ch. 3 i w wykładzie na temat Estetyki Platona w: Plato and Platonism.

${ }^{34}$ K. Schwarzlose, Der Bilderstreit, Gotha 1890, s. 161 i n. 
ku przeznaczenie obrazów ${ }^{35}$. Drugi Sobór Nicejski zadecydował, że obrazy świętych malowane były po to, aby widz mógł uczestniczyć w pewnym uczuciu świętości, jako końcowym rezultacie kontemplacji ${ }^{36}$. To nie cielesna obecność świętych, ale ich święte cnoty mają być przywiedzione do świadomości, powiada Germanus ${ }^{37}$. Miały one oddziaływać na widza i uświęcać go ${ }^{38}$.

Ta koncepcja aktywnej emocjonalnej siły zawartej w obrazie religijnym doprowadziła Grzegorza Wielkiego, około roku 600, do tego, by nazwać ją źródłem „nauki” dla tych, którzy nie mogą czytać Pism. Grzegorz miał na myśli duchowy i moralizatorski wpływ Biblii, jak również obrazów. Gorliwie apelował on do dziewcząt, by czytały Biblię, z tego powodu właśnie, „by wiedziały jak kierować swym życiem i prowadzić gospodarstwo domowe, gdy Bóg Wszechmogący zjednoczy je z ich mężami”39. Z drugiej strony polemiczny sarkazm, z którym św. Augustyn odmawiał racji uważającym przedstawienia za źródło merytorycznej informacji, musiał być Grzegorzowi dobrze znany. Służyły ludziom dobrze, twierdził Augustyn, o ile zostali oszukani ${ }^{40}$.

W odniesieniu do teorii sztuki tamtych czasów, troska papieża Grzegorza o nauczanie doktrynalne poprzez dzieła sztuki była raczej drugo-

35 Mansi, XIII, kol. 103, Św. Nilus (zm. 430) wyraził, w jego często cytowanym liście, właściwie tę samą opinię (PG, LXXIX, kol. 577 i n.). Klasyczny odpowiednik wyraża anegdota o ateńskiej kurtyzanie, która stała się wcieleniem powściągliwości poprzez wpływ portretu filozofa.

36 „(...) można poprzez (...) malowane przedstawienie zostać wzniesionym ku wspomnieniu i pamięci o przedstawianym oraz w pewnym stopniu doświadczyć uświęcenia". Mansi, XIII, kol. 131.

${ }^{37}$ Ibidem, col. 101.

38 Jan z Damaszku, PG, XCIV, kol. 1268: „Obrazy (...) instruują widzów w bezdźwięcznym głosie i uświęcają widok”. Wymienia efekty, op. cit. XCV, kol. 313: „wspomnienie i miłość oraz prawo do przeżywania życia”.

39 Ep. XI, 78 (Patrologia Latina LXXVII, kol. 1219 i n.).

${ }^{40}$ De consensu Evangeliorum, lib. I, par 9 i n. Święty Augustyn nie wyrażał sprzeciwu wobec przedstawień Chrystusa ze świętym Piotrem i Pawłem, choć ten ostatni nigdy nie spotkał Pana. Jednakże: „Zasłużyli na bycie oszukanymi ci, którzy szukali Chrystusa i Jego apostołów nie w Piśmie Świętym lecz na malowanych ścianach: dziwią się, że spekulacje [miast studiów] doprowadziły ich do oszustwa malarzy" (par 10, 16, PL XXXIV, kol. 1049). Arcybiskup Agobard z Lyonu (zm. 840) cytował ten passus jako dowód rzekomej wrogości Augustyna w stosunku do obrazów (Opera, red. S. Baluzius, Paryż 1666, I, 254). Ma ono jednak inny kontekst. Augustyn nie przyznawał sztuce zadania intelektualnego nauczania, lecz uznał, że podąża ona według własnej natury, którą uważał za mocno związaną z dekoracyjnością. W innych wypadkach Augustyn pozostaje podejrzanie milczący $\mathrm{w}$ kwestii nowego podejścia do sztuki. Swego stosunku do muzyki nie rozumiał sam ( $W y$ znania, X, 33); jego intelekt nie mógł zapanować nad emocjami wywołanymi przez muzykę. Muzyka miała na niego natychmiastowy wpływ - sztuka najwyraźniej nie. Por. E. Bevan, Holy Images, London 1940, s. 120 i n. 
rzędna. Głównym przedmiotem jego zainteresowania była emocjonalna i duchowa moc sztuki. Podzielał on pogląd, że była ona zdolna wywołać konkretny efekt u każdego z obserwatorów, efekt niezależny od jego kultury intelektualnej, ale nierozerwalnie związany z przedstawieniem artystycznym. Wierzył on, że kontemplacja przedstawienia wydarzenia lub osoby może wywołać emocje także u tych, którzy nie pojmują intelektualnie znaczenia danego tematu; że ich życie duchowe skierowane zostanie we właściwą stronę ${ }^{41}$. W zamyśle papieża, gdy „niewykształceni” widzą „to, co się dokonało”, doświadczają czynów lub cierpienia na drodze empatii. Papież Hadrian I wskazał kontekst, do którego należą idee Grzegorza Wielkiego, w następujących ich interpretacjach:

(...) święte obrazy (...) są czczone, by sprawić, by nasze umysły, poprzez widzialną zewnętrzną formę, mogły być przeniesione do niewidzialnej chwały Boga, poprzez emocję duchową stworzoną w kontemplacji wizerunku ciała, które Syn Boży przyjął dla naszego zbawienia ${ }^{42}$.

W swej odpowiedzi na Libri Carolini Papież Hadrian zgodził się co do tego, że obrazy są zdolne wywoływać nadprzyrodzone myśli i uczucia43.

Patriarcha Germanus przyznał, że skoro natura człowieka zdeterminowana jest przez jego byt fizyczny, duchowość można wzmocnić poprzez wizualność, co szczególnie przydatne jest tym, którzy nie potrafią wejść $\mathrm{w}$ stan najwyższej duchowej kontemplacji bez odpowiedniej pomocy ${ }^{44}$. To odnosiło się do znakomitej większości rodzaju ludzkiego. Dla Jana z Damaszku kwestią obojętną było czy obiekt prezentowany jest umysłowi poprzez słowa, czy też percepcja jego formy dokonuje się poprzez obraz ${ }^{45}$. W najpiękniejsze słowa ubrał on jednak sposób, w jaki dzieło sztuki wznosi duszę bezpośrednio do Boga, bez uciekania się do intelektu46.

41 Ep. XI, 13.

${ }^{42}$ Monumenta Germaniae Historica Epistolae, V, 56. Mansi XII, kol. 1061 i n.

${ }^{43}$ Ibidem, V, 32. Papież Hadrian I wyraził to stanowisko ustnie w roku 769 (por. K. Hampe, Mon. Germ. Concilia, II, 1, s. 91). Cytował Dionizego Areopagitę, De coelesti hierarchia, rozdział I,3 (PG III, kol. 124). Dionizy zajmował się wprawdzie symbolicznymi znaczeniami postrzegalnego świata, lecz dla średniowiecza istotne było rozszerzenie znaczenia jego słów na wszystkie rodzaje twórczości.

${ }_{44}$ Mansi XIII, kol. 101: „Zmieszani z ciała i krwi osiągamy pewność w sprawach dotyczących duszy również poprzez wzrok”. Kol 116: „Przedstawianie w obrazach natury ludzkiego ciała, jakie przyjął Bóg, służy pewną pomocą tym, którzy (sami) nie są w stanie wznieść się na wyżyny Duchowej wizji...” Kol. 113: „Przedstawiony kształt Jego ciała staje się (...) głównym przewodnikiem (...) w tym obrazie".

${ }^{45}$ De imaginibus oratio, I, PG XCIV, kol. 1248.

46 Ibidem, col. 1268: „Wchodzę do świątyni, a doskonałość malowidła przyciąga moją uwagę i daje wzrokowi rozkosz niczym kwieciste błonie i w niewidoczny sposób przekazuje duszy wizję Boga". 
Im bardziej sztuka staje się emocjonalnie skuteczna - miast mieć jedynie funkcję ilustracyjną - tym bardziej artyści mogą sprawić, że ich punkt widzenia zacznie dominować. Trudno przyjąć za rzecz oczywistą, by chrześcijańscy artyści kiedykolwiek dali się całkowicie uciszyć. Staje się to tym mniej prawdopodobne, skoro rzucano cień wątpliwości na prawo do wykonywania ich sztuki oraz skoro sami klerycy należeli do ich kręgu. Artyści z pewnością dyskutowali o specyficznej wartości sztuki, a autor niniejszej publikacji przekonany jest, że mgliste ślady rozprzestrzeniania się takich dyskusji w pracowniach mogą kiedyś zostać odnalezione.

Nicefor I, patriarcha Konstantynopola (ok. 758-829) definiuje dwa typy dzieła sztuki, zaklasyfikowane według istnienia lub nieistnienia przedmiotu, ustami artysty mówiącego do grupy swych kolegów ${ }^{47}$ : „Przedstawienie rzeczywistości odnosi się do przedstawianego tematu poprzez podobieństwo. Chociaż istota ich jest różna, są w gruncie rzeczy połączone. Obraz przekazuje wiedzę o oryginalnej naturze tematu, tak, że zdaje się on istnieć naprawdę. Obrazy ukazują tematy poprzez kreowanie ich obecności ${ }^{48}$. Skoro widzenie prowadzi do wiedzy lepiej (dosłownie, szybciej) niż słuch i skoro pozostawia większe wrażenie poprzez rzeczywistą i nie wiodącą na manowce obecność, możliwe jest, by przenosiło ono znaczenie klarowniej niż słowa" 49 . Umieszczenie tych słów w ustach artysty czyni je tym godniejszymi uwagi, choć w rzeczywistości były sumą nauk teologów. Jednak to, że artyści brali udział w tych dyskusjach może być rozpoznane z samych argumentów, gdyż opierają się one raczej na czynnikach empirycznych i psychologicznych niż na myśli teologicznej. Hraban Maur w Poemacie 38 - przewyższył nawet Libri Carolini $\mathrm{w}$ swych oskarżeniach skierowanych przeciwko obrazom zniekształca-

47 Antirrheticus, I, 28; PG C, kol. 277. Granica nie biegnie pomiędzy obszarami idei i widzialnego, ale pomiędzy materialnym lub metafizycznie rzeczywistym a czystą wyobraźnią. Była to doktryna niewątpliwie Epikurejska, zob. Lukrecjusz, De rerum natura IV, 722. F.A. Gasquet, The Eve of the Reformation, Londyn 1919, s. 258 oraz 268, cytuje odpowiednie późnośredniowieczne źródła.

48 Antirrheticus, I, 30; III, 5, op. cit., kol. 280, 381 i n.

49 Ibidem, III,3 (kol. 380 i n.) - Już św. Augustyn, podążając za ideą Platona, nadał wzrokowi naczelną rolę wśród zmysłów (Wyznania, X,35; zob. także sermo 112 VI, VI,7). To twierdzenie znane jest historykom sztuki pośrednio poprzez wypowiedź Albrechta Dürera. Nie jest jasne skąd zaczerpnął on tę myśl, która była jednak dość popularna. Franciszkanin stwierdził, około roku 1428, że wzrok jest „eindrucksvoller, edler, stärker als das Gehör" (C.F. Arnold, Geschichtliche Studien für Albrecht Hauck, Lipsk 1916, s. 200). Najbardziej niesamowitym dzieckiem tej teorii była koncepcja Richarda Wagnera (Das Kunstwerk der Zukunft, 1849), wedle której sztuka pozostaje niesatysfakcjonująca dopóki nie zaspokaja wzroku; por. E. Newman, Richard Wagner, Nowy Jork 1941, s. 187 i n. 
jącym, jego zdaniem, prawdziwe znaczenie tematu, co w rzeczywistości mogło być związane $\mathrm{z}$ negatywnym stosunkiem teologa do niechcianej konkurencji.

Nie możemy, ani nie ma tutaj potrzeby badania rozwoju teologicznej doktryny zdolności człowieka do osiągania metafizycznej wiedzy, na bazie relacji „obrazowej”. Musimy jedynie być świadomi, że ocena sztuki figuratywnej jako równoważnej i niezagrożonej przez słowa w życiu religijnym miała swój odpowiednik w relatywistycznej ocenie ludzkiego języka. Pisma Hugona od Św. Wiktora (1096-1141) wskazują kierunek wychylenia wahadła. W jego opinii słowa stworzone są przez człowieka, a ich znaczenie ustanowione jest przez arbitralną konwencję. Stąd, dla zrozumienia sensu Pisma Świętego, pozbawione słów objawienia istoty Stworzenia są o wiele ważniejsze, aniżeli słowa, poprzez które człowiek sens ów sformułował, ponieważ wszelkie widzialne i niewidzialne aspekty muszą być uwzględnione ${ }^{50}$. Skodyfikowano tu więc zasady biblijnej hermeneutyki. Ustalono tym samym pewną hierarchię środków wyrazu, wedle której mowa jest narzędziem drugorzędnym $\mathrm{w}$ stosunku do wiedzy uzyskanej bez pośrednictwa słów. Wystarczy tylko tę degradację skontrastować $\mathrm{z}$ formułą Akwinaty, który uznaje, że Biblia jest Słowem Bożym. Zgodnie z wolą Bożą jednak to, co wyrażone jest słowami, może uzyskać znaczenie poza aspektem werbalnym ${ }^{51}$. Jakikolwiek nie byłby powód do krytyki teorii Hugona od św. Wiktora, wyzwaniem dla miłośników sztuki byłoby wykazanie, że sztuka powstała z niewerbalnych wizji, tworzyła w widzu pożądane wrażenia bez udziału słów. Ponieważ słowa nie były wolne od nieporozumień i wymagały wyjaśnienia, nie miały przeto żadnej znaczącej przewagi nad obrazami.

Dla chrześcijańskiej koncepcji świata rzeczywistość ziemska dawno przerosła ograniczenia sfery widzialnej. Wszelka pozbawiona aspektu boskości rzeczywistość potencjalnie pozbawiona była stałych znaczeń; mogła oznaczać to, co widziały w niej ludzkie siły percepcji, lub stać się symbolem tej lub innej rzeczywistości w świecie obecnym lub transcen-

50 Hugon od św. Wiktora, De sctipturis et scriptoribus sacris, cap. 14: „Filozof (Arystoteles) znał tylko znaczenie słów w swoich księgach; lecz w Piśmie Świętym znaczenie rzeczy jest znacznie ważniejsze niż słów, ponieważ te ostatnie są jedynie zwyczajowe, podczas gdy te pierwsze są urządzone przez naturę. Te ostatnie są językiem człowieka, te pierwsze zaś słowami Boga skierowanymi do człowieka. Znaczenia słów stworzone są przez człowieka, rzeczy zaś czerpią swe znaczenie z natury i z woli Boga, który sprawił, iż jedne rzeczy znaczone są przez drugie. Znaczenie rzeczy jest również o wiele bardziej złożone niż znaczenie słów. Niewiele słów ma dwa lub więcej znaczeń, podczas gdy każda rzecz może oznaczać wszystkie te rzeczy, z którymi dzieli cechy widzialne i niewidzialne." (PL CLXXV, kol. 20 i n.)

51 Summa Theologica I qu. I, a. X. 
dentalnym. „Lew” mógł oznaczać zwierzę, Chrystusa lub Szatana52. Czyż Chrystus sam nie powiedział (Mk 4, 11,12; conf. Mt 13,13): „Wam dana jest tajemnica królestwa Bożego, dla tych zaś, którzy są poza wami, wszystko dzieje się $\mathrm{w}$ przypowieściach, aby patrzyli oczami, a nie widzieli, słuchali uszami, a nie rozumieli (...)" [wg. Biblia Tysiąclecia, wyd. Pallottinum, Poznań 2003 - przyp. tłum]. Jeśli słowa, rzeczy i zdarzenia tracą swoje oczywiste znaczenie, to ich relacja do rzeczywistości musi być płynna.

Pośród najbardziej złożonych problemów chrześcijańskiej sztuki religijnej godnym uwagi jest Krucyfiks, który stał się jednym z kluczowych punktów kontrowersji ikonoklastycznej. Temat ten mógł zostać zinterpretowany racjonalnie przez widza $\mathrm{w}$ jeden tylko sposób - jakaś postać umiera lub już umarła na krzyżu. Jak napisał biskup Klaudiusz z Turynu (818-827) przedstawienie to mówi nam tylko, „że umarł i wciąż cierpi”53. Jednak chrześcijanie musieli być przygotowani na doświadczenie żywego Boga w umierającym lub martwym ludzkim ciele; na doświadczenie transcendentalnej Prawdy ukrytej za materialnym kamuflażem.

Nie potrafię dokładnie określić, w którym momencie osiągnięto ostatnią fazę ewolucji, kiedy to można było otwarcie stwierdzić, że sztuka religijna potrzebowała wolności $\mathrm{w}$ wizualizowaniu prawdy lub nawet wolności od samej prawdy, a teologiczny adwersarz uznałby taki osąd za „niemal racjonalny”. Wszelako co najmniej od początku XIII wieku roszczenie autonomii $\mathrm{w}$ relacji między przedstawieniem a obrazowanym tematem mogło być uzasadnione nawet bez odwoływania się do jakiegokolwiek innego znaczenia duchowego aniżeli emocjonalne. Około 1230 roku Biskup Łukasz z Tuy w Hiszpanii dostarczył tej tezie odpowiedniego dowodu ${ }^{54}$.

52 Przykład zaczerpnięty z traktatu Jonasza z Orleanu, cytowanego w przypisie 53, col. 358, w którym nie wspomniał o dosłownym znaczeniu słowa.

${ }^{53}$ Cytat za Jonaszem z Orleanu, De cultu imaginum, lib. I; PL CVI, kol. 334.

54 Twierdzenie to jest częścią polemiki Łukasza przeciw nowym typom przedstawień Ukrzyżowanego (De altera vita lib. II, cap. 9; Bibliotheca maxima veterum partum, vol. 25, Lyon 1677, s. 122). Oskarża on Albigensów o wykorzystywanie artystycznych przedstawień w celach propagandowych. „Alius mediantibus picturis est haereticis modus decipiendi (...) Depingunt plerumque deformes sanctorum imagines, ut earum intuitu devotio simplicis Christiani populi vertatur in taedium. In deris[i]um etiam et opprobrium crucis Christi imaginem crucifixi unum pedem super alium uno clavo figentes (...)” „Innym środkiem wykorzystywanym przez heretyków do zwodzenia ludzi są obrazy (...) Malują nadzwyczaj zniekształcone obrazy Świętych, które mogą zamienić pobożność zwykłych Chrześcijan w obrzydzenie. Na urągowisko i aby znieważyć Krzyż, przedstawiają postać ukrzyżowanego Chrystusa, którego stopy, ułożone jedna nad drugą, przebite są tylko jednym gwoździem (...)” Argumenty broniące takiego krucyfiksu płyną w jego pismach, z ust heretyka lub artysty, analogicznie do „haereticus seu pictor”, do którego zwraca się w aka- 
Skoro celem sztuki religijnej jest wzbudzić emocje u widza, artysta musi mieć wolność komponowania swojego dzieła tak, by zapewnić im jak największą efektywność. Przedstawienie nie zawsze musi mieścić się w ramach tradycji. Aby uniknąć nudy zwyczajowych formuł, artysta potrzebuje wolności, by wymyślić odmienne motywy i stworzyć takie nowe idee, które wydadzą mu się stosowne przy poszanowaniu umiejscowienia dzieła i jego czasu, nawet jeśli będą one sprzeczne z dosłowną prawdą i służyć będą jedynie pogłębieniu miłości do Chrystusa, poprzez emocje, które wzbudzą.

To konstatacja przeciwnika takiej wolności, ale jego relacja jest pisemnym świadectwem pokrywającym się z praktyką, dla której malarskie i rzeźbiarskie świadectwo jest nader bogate. Jeśli wsłuchamy się bliżej, polemikę z tym, co zostało nazwane kłamstwem sztuki, sprzeciwiającym się dogmatycznej poprawności oraz jej pozowaniu na niezależnego przewodnika, znajdziemy w innych słownych świadectwach. Poniższy cytat pochodzi z kazania angielskiego księdza z późnego XIV wieku ${ }^{55}$ : „Widzimy, że obraz, jeśli jest prawdziwy, bez dodatku kłamstw, jeśli nie jest nazbyt gorliwy w obfitym karmieniu ludzkiego umysłu, ani nie jest dla ludzi okazją do idolatrii, służy, niczym nagie litery uczonemu, jedynie odczytywaniu prawdy".

Nawet jeśli biskup Łukasz stworzył argumentację przeciwko której sam występował, nie straci ona swojego znaczenia $z$ naszego punktu widzenia, ponieważ nazwał ją „niemal racjonalną”. Rozważa w pewnym miejscu przyczynę, dla której obrazy ukazywane były w Kościele (II,2); czasem działały jak zaklęcie, w innych zaś przypadkach funkcjonowały

picie 9. „Sed dicat aliquis, ad hoc uno pede super alio uno clavo dicimus Dominum crucifixum, et consuetudines Ecclesiae volumus immutari, ut maiori acerbitate passionis Christi populi devotio excitetur et novitate in consuetudinibus succedente fastidium relevetur. Non enim sunt ista de Sacramentorum substantia, vel articulorum fide (...) Sufficit ad salutem Christum credere crucifixum et pro indifferenti habere in cruce illum quatuor vel trium brachiorum fuisse positum, quatuor vet tribus clavis confixum (...) Etiam alqua figenda sunt pro loco et tempore, quamvis vera non sint, ut Christi nominis gloria dilatetur. Haec et huis modi illis quasi rationabiliter asserentibus (...)” „Ktoś mógłby rzec, że Pan został ukrzyżowany z jedną stopą nad drugą i że przebito je jednym gwoździem oraz że chcemy zmienić praktykę Kościoła, tak by pobudzić u ludzi większą nabożność poprzez intensyfikację męki Chrystusa i by zapobiec znudzeniu poprzez zastępowanie zwyczajów czymś nowym. Ponieważ nie należy to ani do Sakramentów ani też do artykułów Wiary (...) Do zbawienia wystarczy wierzyć, że Chrystus został ukrzyżowany i uznać nieistotnym czy był to Krzyż o czterech czy trzech ramionach, czy był przybity czterema czy też trzema gwoździami (...) Nawet zdarzenia mogą być przedstawiane w zgodzie z wymogami miejsca i czasu, nawet gdyby miały być nieprawdziwe, celem głoszenia chwały imienia Chrystusa. W taki sposób się wypowiadają, co zdaje się niemal racjonalne.”

55 J. Halliwell-Phillips, Reliquiae antique, Londyn 1983, II, s 42 i n. Jestem zobowiązany wobec Claude’a M. Simpsona Jr. z Uniwersytetu Harvarda za jego pomoc w przełożeniu tego zdania na współczesny angielski. 
jako dekoracja. Ale oczekiwał on od dzieła sztuki wywołania reakcji emocjonalnej i wpływu na duchowe życie widza. W swoich oczekiwaniach nie różnił się on od artystów. Powołując się na Księgę Hioba (Hi 13,7) nie akceptował odstępstw od prawdy, i jak wielu tak czyniło, oczekiwał od sztuki piękna, uznając tylko styl tradycyjny, do którego przywykł, nie zaś trendy sztuki współczesnej. Artyści nie pozostawali pod wrażeniem takich standardów estetycznych i nie można ich raczej winić za to, że nie wspierali zbyt ochoczo jego postulatu dosłownej prawdy w sztuce. „Chrystus był przybity do Krzyża nagi; odpowiednio w nagiej prawdzie winni wierni głosić Jego imię" wołał Łukasz (II, 10). Na to mógłby odrzec artysta: „Panie mój, byłbyś pierwszym, który wyrzuciłby z kościołów przedstawienia ukazujące Go na Krzyżu nagim - jak głosi historia i doktryna. Jeśli odstępstwa od prawdy są właściwe w imię przyzwoitości, czy nie są równie właściwe, by pobudzać pobożność?"

Starożytni artyści nie prosili o tak wielką niezależność od rzeczywistości. Lecz Eratostenes w III wieku p.n.e. uwolnił poezję od całej jej funkcji dydaktycznej lub jakiegokolwiek związku z Bytem i widział jej sens wyłącznie w pobudzaniu emocji ${ }^{56}$. Podobnie Filodemos (I wiek p.n.e.) dał poezji autonomię w zmierzaniu się $\mathrm{z}$ tematami ${ }^{57}$. Horacy (Ars Poetica 9 i n.) zezwalał artystom na taką samą wolność, jak poetom w zdaniu, które stało się dla nich przepustką do emancypacji i cytowane było przez biskupa Duranda z Mende (ok. 1290), niejako w uznaniu takiego autorytetu $^{58:}$ : Lecz malowane są również inne historie ze Starego i Nowego Testamentu zgodnie $\mathrm{z}$ wolą malarzy, gdyż

\section{(...) pictoribus atque poetis \\ Quidlibet audendi semper fuit aequa potestas!”}

Biskup Durand nie zajmował się wolnością artystów jako taką, lecz jedynie swoimi interpretacjami biblijnych zdarzeń. Zatem jego wypowiedzi nie mogą być uznawane za wsparcie dla niezależności sztuki, tym bardziej nie czuł on potrzeby dodania jakichkolwiek zastrzeżeń.

Teologia wciąż uznawała obie teorie, co pozostawiało miejsce dla samoistnej wartości sztuki religijnej. Uznawano jej unikalną wartość emocjonalną. Dzieła sztuki, wedle św. Tomasza z Akwinu (ok. 1255) są właściwymi środkami do pogłębiania pobożności, skoro wzbudzana jest

${ }^{56}$ H. Mutschmann, w: Hermes, 52, 1917, s. 190 i n.

57 A. Rostagini, w: Atene e Roma, N.S. , 1920, s. 55.

${ }_{58}$ Rationale divinorum officiorum I, 3 n. 22 (zob. Didron, Manuel d'Iconographie chretiénne, Paryż 1845, s. VII) „Pictoribus atque poetis semper fuit et erit equa potestas”, posłużyło za motto w szkicowniku ucznia Benozzo Gozziliego, zob. Old Master drawings, 4, 1929-1930, s. 53. 
ona prędzej przez wizualność, niż wrażenia słuchowe ${ }^{59}$. Biskup Durand podał przyczynę takiego stanu rzeczy: „zdarzenie przedstawiane jest oczom przez obraz, a [jedynie abstrakcyjnie] przywołane do umysłu poprzez słuch, który czyni w umyśle mniejsze wrażenie niż widzenie"60. To znany już argument o większej doniosłości rzeczy postrzeganych, który był wielokrotnie powtarzany ${ }^{61}$. Druga teoria miała pośredni wpływ na ocenę sztuki. Co najmniej do XVI wieku zakładano, że ludzki umysł zdolny jest dotrzeć do nadprzyrodzonego za pomocą „widzialnych” rzeczy, czy to wyobrażonych, czy realnych ${ }^{62}$. „Właściwym przedmiotem ludzkiego umysłu jest istota lub natura istniejąca w cielesnej materii i przez taką naturę rzeczy widzialnych, urasta ona również do pewnej wiedzy o rzeczach niewidzialnych", stwierdził św. Tomasz ${ }^{63}$. Ponieważ nadprzyrodzone nie może być zrozumiane przez człowieka „bez płaszcza zewnętrznego kształtu"64, artyści dostali swą szansę. Mogli bowiem uznać, że zmaganie się z wizualizacją niewyrażalnego i niepojmowalnego było zadaniem ponad ograniczenia teologii, która związana jest z użyciem słów. Każda definicja jest ograniczeniem, jak mawia stare przysłowie. Nawet teolodzy, tacy jak Thomas Netter (Waldensis zm. w r. 1430), którego nauki o obrazach nie są użyteczne w kontekście naszych dociekań, broni wolności sztuki do wizualizowania tego, co próbujemy zdefiniować słowami65. Teolodzy, rzecz jasna, wciąż wyrażają konieczność „podobieństwa” w obrazach $^{66}$, ale miało to niewielki wpływ na średniowieczną sztukę Zachodu.

59 Scriptum super sententias III. dist. 9 qu. I, a. 2, sol. 2.

60 Op. cit., I, 3 do I, 4. Ksiądz Jan, który reprezentował na Drugim Soborze Nicejskim trzy biskupstwa - Aleksandrii, Antiochii i Jerozolimy stwierdził: „(...) silniejszym niż słowo jest obraz, a jest tak przez bożą Opatrzność ku korzyści niewykształconych”. Mansi, XIII, kol. 20.

${ }^{61}$ Np. wpływowa Summa, cap. V dominikanina Raineriusa z Pizy (zm. 1348) nauczała identycznie jak św. Tomasz; podobnież dzieło Jeana Gersona (1362-1428), Wenecja 1587, fol. $30 \mathrm{r}$.

$62 \mathrm{O}$ poziomie pobożności praktyk: Johannes Mauburnus, Rosetum exercitiorum spiritualium, Douai, 1620, s. 411. Mauburnus był holenderskim augustianinem zmarłym w roku 1501. Jego dzieło wydrukowano po raz pierwszy w 1494 roku.

63 Summa Theologiae, I, qu. 83, a. 7. Zacytowane przez autora oryginalne tłumaczenie pochodziło od angielskich dominikanów, 2 wyd., Londyn 1922 [brak tytułu dzieła - przyp. tłum.]. Twierdzenie to należy do dyskusji o logice. Mało kto zdaje sobie sprawę, że w istocie św. Tomasz napisał tylko kilka zdań odnoszących się do sztuki w sposób bezpośredni. Mówiąc o ars nie miał na myśli sztuki, lecz każde rzemiosło lub zawód; nie miał on na myśli specyficznych cech sztuki, ale te które dzieli z konstruowaniem pługów, pieczeniem chleba czy operacjami chirurgicznymi. Dla Tomasza cechy te nie mogły być więc w sztuce najważniejsze.

64 Św. Tomasz, Summa Theologiae, IIa, IIae qu. 174, a. 2.

65 Netter rozważa przedstawienia Trójcy; De sacramentalibus, XIX, kol. 155.

66 Również dla św. Tomasza podobieństwo było istotą imago; por. Summa, I, qu. 93, a.II.2. Powszechnie wiadomo, że Max Dvořák zinterpretował źródła pisane w swej rozpra- 
W zasadzie rzeczą artysty było ustalić, co sam rozumie przez „podobieństwo”. Co więcej, generalne rozumienie „podobieństwa” nie było identyczne w różnych okresach. W czasach średniowiecza podobieństwo mogło być konstytuowane przez podobieństwo idei leżących u podstaw różnych realizacji. Takiemu pojmowaniu tej kwestii brakowało mocy ograniczania sztuki, która, jak wierzono, miała prawo przetwarzania rzeczywistości zgodnie $\mathrm{z}$ artystycznymi potrzebami.

Istnieli, rzecz jasna, członkowie kleru, którzy wyczuwali niebezpieczeństwo w dziełach sztuki, gdyż mogły zmącić czystość wiary, jeśli, zamiast wywoływać reakcje emocjonalną, wzięte zostałyby za odpowiednik rzeczywistości. Niemniej jednak, co do zasady, kościelne autorytety zdawały się unikać otwartego konfliktu z artystami, chociaż uznawały ich za całkowicie odpowiedzialnych za swe dzieła. Jeśli sztuka byłaby nie tylko „pod ścisłą kontrolą, ale i nadrzędną władzą kleru”67, to można by się spodziewać, że obwiniani byliby ci z duchownych, którzy eksponowali dogmatycznie niepoprawne dzieła sztuki, a nie ci, którzy rzekomo wykonali to, co im zlecono. Ale w rzeczywistości to na artystów spadało potępienie, co było równoznaczne niechętnemu pogodzeniu się z autonomią, którą uzyskali. Święty Antonin, arcybiskup Florencji (1389-1459) napisał dobitnie: „(...) należy winić malarzy, jeśli to, co malują, wchodzi w sprzeczność z Wiarą"68. Cytował pośród takich sprzeczności Zwiastowania ukazujące Dzieciątko. Biskup Łukasz z Tuy nie winił natomiast księży, którzy powiesili „wypaczone” obrazy w celu dotarcia do ludzi, ale artystów za ich stworzenie (II,9). Zarówno on, jak i biskup Radulph z Londynu w $1306^{69}$, widzieli w krucyfiksach widlastych z ukośnie wznoszącymi się ramionami, inwencję artystów (il. 10). Biskupi oskarżyli ich o brak zrozumienia dla mistycznego znaczenia tradycyjnego krzyża. Nie połączyli krzyża widlastego z Drzewem Życia, jak dziś się to zwyczajowo czyni, pomimo faktu, że powiązanie to i tak nie tłumaczy ukośnego kierunku wznoszenia się ramion krzyża ${ }^{70}$. Polemika biskupa Łukasza jest niemal

wie Idealismus und Realismus in der gotischen Kunst, Monachium 1918, w nadzwyczaj niefortunny sposób. Odnosi się to również do strony 35.

67 Paul Keppler, który został biskupem rzymskokatolickim w Wirtembergii, w: Goerresgesellschaft, Historischer Jahrbuch, IV, 1883, s. 183. 68. Summa III, tu. 8 cap 4 par. II.

68 [w tekście oryginalnym odniesienie do przypisu $\mathrm{nr} 68$, lecz brak przypisu - przyp. tłum.]

69 R.C. Fowler, Registrum Radolphi Waldock; The Canterbury and York Society, Londyn 1841, s. 19. (Sądzę, że powinno się czytać in patibulo sine ligno transversali). Biskup zapobiegł użyciu takiego typu krzyża w jego diecezji. Rzeźbiarz był Niemcem.

70 Por. np. Künstle, op. cit., I, s. 468 i n. (Nie poczyniono rozróżnienia pomiędzy krucyfiksem widlastym, a krzyżem w tradycyjnej postaci, zrobionym z gałęzi, a także Drzewem Życia lub Drzewem Krzyża). Najstarsze przykłady krucyfiksów widlastych pochodzą z pracowni Bonawentury Berlingheriego w Lukce. Najbardziej charakterystyczny przykład po- 
tak dawna jak najwcześniejsze znane przykłady takich krucyfiksów. Musiał on wiedzieć, czy reprezentowały one idee teologów, czy też nie. Im bardziej wertykalnie ustawiano ręce Chrystusa, tym bardziej zdawały się skrępowane. W celu osiągnięcia tego waloru ekspresji, motyw skośnych ramion wykorzystywany był przez artystów tak wtedy, jak i dziś; jednakże wydaje się, iż nie stał on się częścią stałej tradycji ikonograficznej.

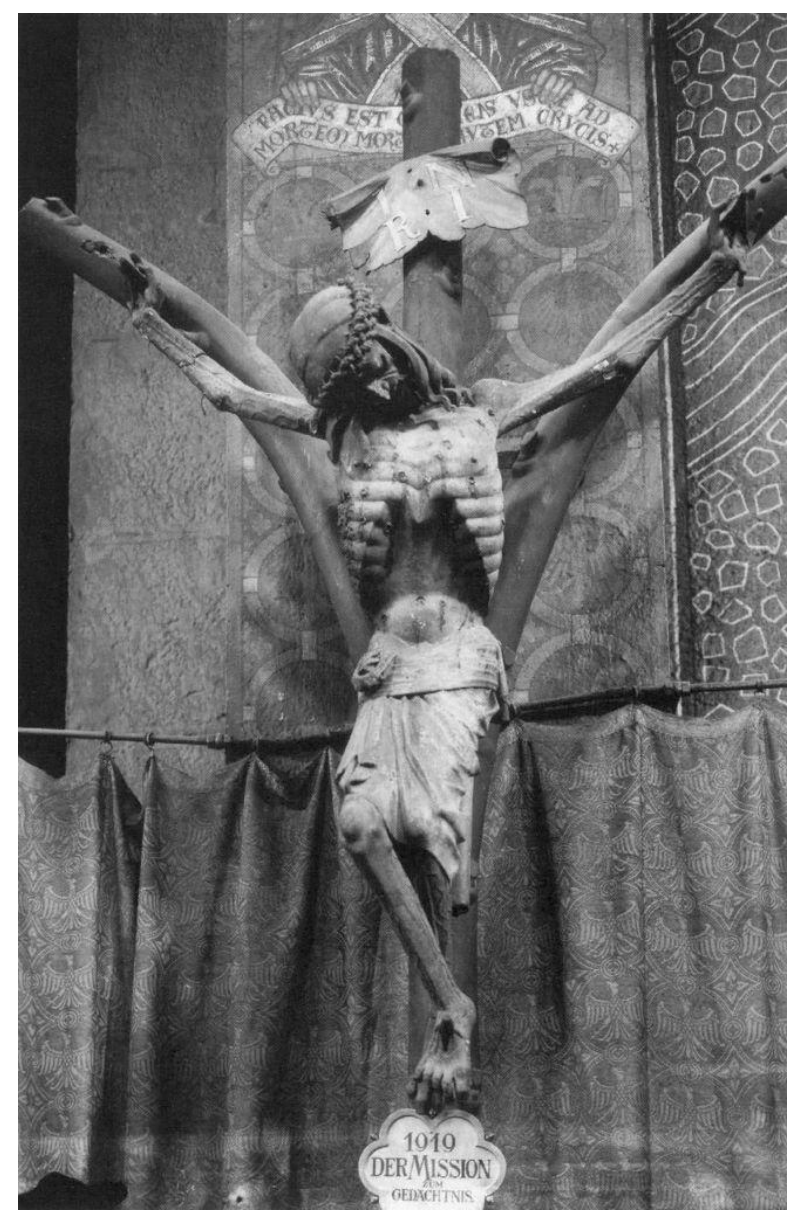

10. Krucyfiks widlasty, Nadrenia, NMP na Kapitolu, Kolonia, 1304

chodzi z wielkanocnego lichtarza w Gaecie, gdzie prosty krzyż wykonany został z dwóch desek (zob. E. Vavála, La Croce dipinta Italiana, Verona 1929, il. 458, s. 714 oraz il. 25). Najważniejszym wizualnym dowodem na przeszczepienie niezależnie rozwiniętego krucyfiksu widlastego do schematu drzewa jest relikwiarz w formie krzewu różanego w kościele S. Francesco w Lucignano z około 1350 roku. 
Są to przykłady podejścia hołdującego dyscyplinie - w żadnym razie nie dominującego. W dyspucie pomiędzy dominikaninem a franciszkaninem około 1428 roku, pośród dyskutowanych tematów znalazła się wolność artystów ${ }^{71}$. Dominikanin stwierdził raczej w sposób oderwany od rzeczywistości, że „nikomu nie wolno wymyślać nowych i indywidualnych przedstawień dla pobożności prostego ludu, bez zgody Ojca Świętego. (...)”. Franciszkanin słusznie odparł, „że [procedura ta] nie była konieczna dawniej jak również nie jest oczywiście konieczna dzisiaj”. Jako dowód przytacza opowieść o malarzu, który przybył z Norymbergi do Wrocławia i wymyślił wiele uprzednio nieznanych przedstawień Chrystusa, Dziewicy i Świętych, bez ingerencji autorytetów kościelnych.

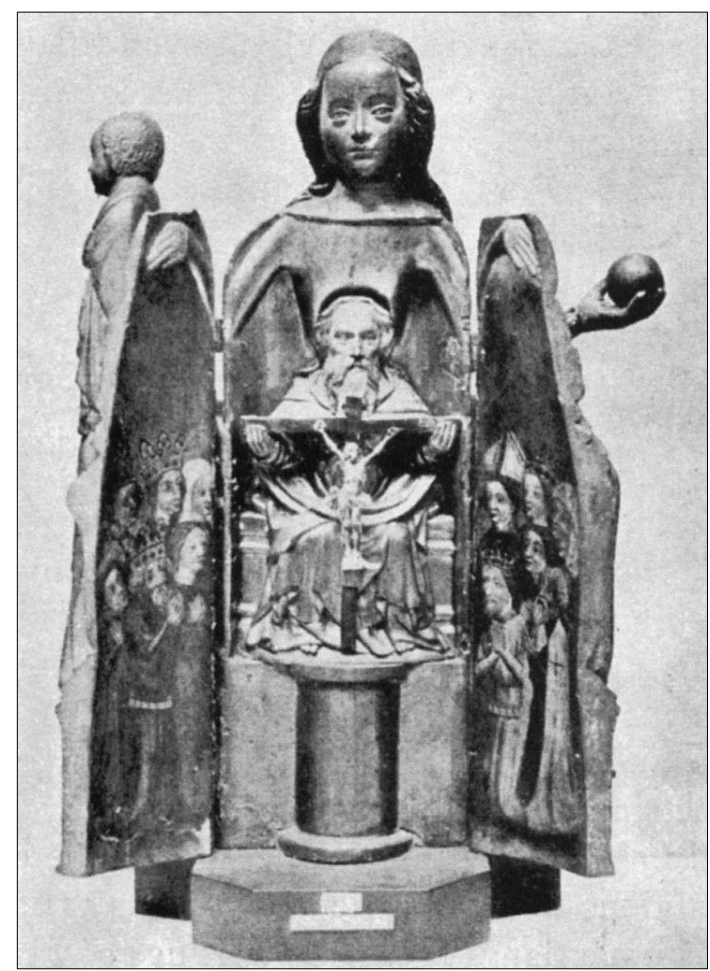

11. Madonna szafkowa, wschodnie Niemcy, ok. 1390, Muzeum Cluny, Paryż

Pobłażliwy stosunek Kościoła jest nawet bardziej uderzający w kazaniu Jana Gersona z około 1400 roku, ponieważ słowa wypowiadane były w tonie krytycznym ${ }^{72}$. Obrazy nie są tworzone „dla żadnej innej przyczy-

71 Por. wyżej przypis 49.

72 Opera Omnia, Anvers 1706, T.2, kol. 947. 
ny, niż pokazanie prostym ludziom, nieświadomym Pisma, w co muszą wierzyć. A zatem, należy wystrzegać się przyjmowania za prawdziwe każdego nieprawdziwego przedstawienia, które objaśnia Pismo Święte niewłaściwie". Gerson mówi, że stwierdzenie to, którego pierwsze zdanie staje w sprzeczności z jego Summa ${ }^{73}$ było po części wywołane przez Vierge Ouvrante w kościele Karmelitów w Paryżu (il. 11). Przedstawienie to było zdecydowanie niedogmatyczne, ponieważ ukazywało Trójcę Świętą jako wcieloną. Można się spodziewać, że takie przedstawienia były nie do zaakceptowania przez karmelitów ipso facto, jak i przez Gersona. Jednak karmelici nie wyrażali sprzeciwu wobec eksponowania takiej „Matki Bożej” i sam Gerson czuł potrzebę dalszego wyjaśnienia swej dezaprobaty: „Doprawdy nie rozumiem dlaczego takie dzieła są czynione. Bowiem, w mojej opinii, brak im piękna, nie są także nabożne, lecz mogą wytworzyć błędną wiarę i utratę pobożności”. Najwyraźniej nawet dla Gersona piękno i nabożność przeważały nad dogmatyczną poprawnością. Pozostawiał księżom - podobnie jak czynili to karmelici - upewnienie się, czy dogmatyczne wierzenia są podtrzymywane pomimo niedogmatycznego przedstawienia.

Koncepcja niezależnej, emocjonalnej wartości sztuki była tak głęboko zakorzeniona wśród teologów, że nawet Marcin Luter zaakceptował Zwiastowanie przedstawiające Dzieciątko niosące krzyż (il. 12). Uczynił tak ze względu na ludzi prostych, opierając się na proroctwie Izajasza (Iz 9,6) ${ }^{74}$. Ale dla „zwykłego” rówieśnika Lutra, przedstawienie to nie mogło znaczyć wiele więcej niż to, że „Bóg” cierpiał lub był świadom nadchodzących cierpień jeszcze przed wcieleniem. Obie koncepcje stały się popularne od drugiej połowy XV wieku, kiedy cytowano najczęściej następujące fragmenty Pisma Świętego: Sdz 13,7 oraz Ap 22,12. Tylko uczony protestant mógłby skojarzyć wrażenie wizualne z wersetem z Izajasza, wersetem, który sztuka wizualizowała na kilka sposobów, ale zawsze z nim w zgodzie, pokazując Dzieciątko po narodzeniu. Luter nie wyraził sprzeciwu wobec heretyckich koncepcji przedstawienia i oczekiwał, by prawdziwe znaczenie było rozumiane bez jakiejkolwiek wizualizacji.

Pomimo odnowienia kontrowersji ikonoklastycznych, decyzje dwudziestej piątej sesji Soboru Trydenckiego w 1563 roku nie ukróciły w sposób kategoryczny niezależności sztuki w kreowaniu rzeczywistości. Próbowano nawet ograniczyć ingerencję władz Kościoła, do którego należało wykonanie soborowych decyzji. Jedynie eksponowanie obrazów zdolnych wśród nieuczonych przysporzyć „niebezpiecznych błędów” było zakazane.

${ }^{73}$ Zob. wyżej przypis 61.

${ }^{74}$ Auslegung der Evangelien, Wittenberg 1532, T. II, fol. XXVIII v. 


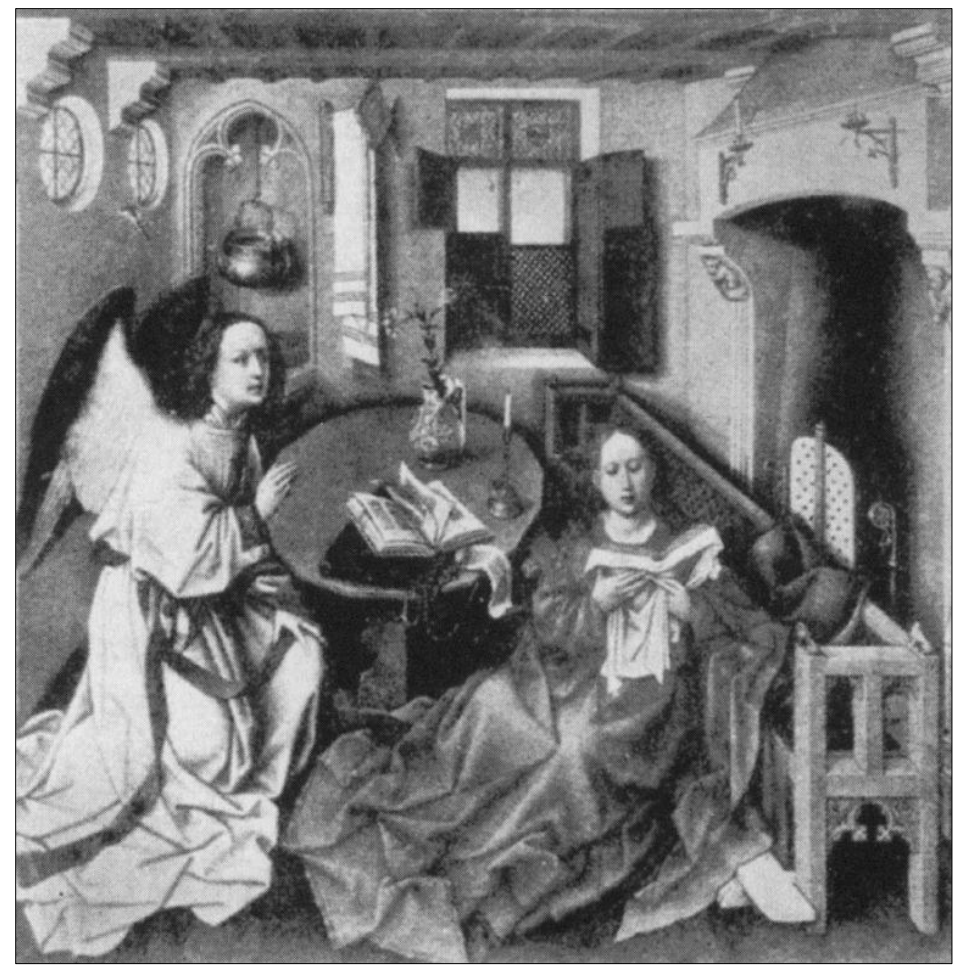

12. Mistrz z Flémalle, Zwiastowanie, ok. 1428, Cloisters, Nowy Jork

Przedstawienie nie mogło być odrzucone tylko dlatego, że zdolne było sprokurować powstanie błędu dogmatycznego; błąd ten musiał być niebezpieczny. Ponadto Sobór zakazał eksponowania „nietypowych” obrazów bez uprzedniej zgody ordynariusza. Ale postanowienia soborowe odnosiły się jedynie do przyszłości; nie powiedziano nic przeciwko wcześniejszym obrazom. Johannes Molanus, autor klasycznej rozprawy teologicznej dotyczącej sztuki religijnej, zinterpretował to milczenie jako dowód, iż żadne $\mathrm{z}$ istniejących w kościołach obrazów nie były niebezpieczne ${ }^{75}$; iż nikogo nie wprowadzą one w błąd; lecz jeśli nawet tak się stanie, to osoba ta musi zostać wyprowadzona z tego błędu za pomocą nauk (II,25). Był przeciwny pochopnemu odrzuceniu obrazów, które zostały zaakceptowane za powszechną zgodą, lub zrodziły się z popularnej pobożności (II,30). Utrzymywał, że żadna osoba nie miała prawa zakazać dawnego obrazu, a prawo to należało jedynie do Kościoła (II,24). Bronił jednak praw teolo-

75 Pierwsze wydanie: De Picturis et Imaginibus sacris, Louvain 1570; drugie wydanie opatrzone tytułem: De historiae SS. Imaginum, wyd. H. Cwyckins, Louvain 1594; trzecie wydanie, wyd. J.N. Paquot, Louvain 1771. 
gów do dogmatycznego sądzenia poprawności sztuki (II,26) i zalecał instruowanie artystów tak, by mogli unikać poważnych i istotnych błędów (II,28). Gdyż, co było zabronione w druku, było także zabronione w obrazach, bowiem nawet uczeni często pozostawali pod ich wpływem. Cytat z Horacego nie był aktualny dla sztuki religijnej i zawsze wymagano zastrzeżenia, żeby nie pokazywano nic obscenicznego (II,2). Wyrozumiały stosunek Molanusa do sztuki wynikał ze skłonności do unikania czegokolwiek, co mogło być szkodliwe dla pobożności, poprzez odcięcie związków ze zwyczajowymi typami przedstawień. Molanus, teolog zwracający się do teologów, kierował się względami troski o duszę, a nie o sztukę ${ }^{76}$. Lecz nawet po Trydencie zwyczajne względy estetyczne mogły przeważyć nad prawdą. Jezuita Francesco Suarez (1548-1617) nazwał błędem przedstawienie Marii mdlejącej podczas złożenia do grobu. „Lecz być może nie chciano wyrazić bezgranicznego cierpienia na obrazie w sposób inny, niż ten"77. Omdlenie może wydawać się godniejsze estetycznej aprobaty niż grymasy twarzy.

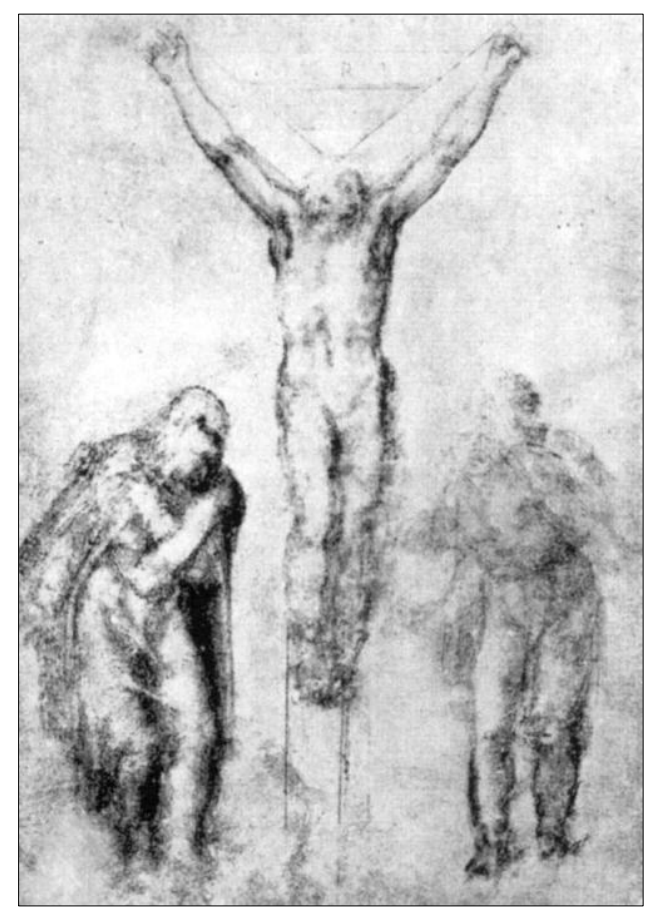

13. Michał Anioł, Ukrzyżowanie, rysunek, ok. 1540, Luwr, Paryż

76 Potrzeba uzupełnienia historii przez przedstawienie wyrażona jest w II, 19.

77 Commentaria (...) in tertiam partem D. Thomar; quaest. XL VI. art., VIII, disput., XXXV, sect. III, 11 (Opera, vol. 19, Paryż 1866, s. 692). 
Obecnie niewiele wiadomo jest na temat ikonografii chrześcijańskiej po trwałym ufundowaniu się Kościołów protestanckich, które zmieniły klimat, w jakim Kościół rzymskokatolicki musiał istnieć. Jednak chyba nie mylę się sądząc, że śmiałość i innowacyjność nowych motywów połączona $\mathrm{z}$ przechowaniem starych motywów nieortodoksyjnych, przeniesiona została do sfery obrazów dewocyjnych, podczas gdy co do zasady, tak zwana sztuka wysoka stała się ostrożna i konwencjonalna w interpretacji tematów religijnych. Otchłań zaczęła otwierać się za życia Michała Anioła (1475-1564) oraz Rubensa (1577-1640). Jeżeli którykolwiek z artystów mógłby ukrzyżować Chrystusa na krzyżu widlastym, z pewnością byłby to Rubens, jednak w jego świecie duchowym nie było miejsca na typy nieortodoksyjne. Z drugiej strony Michał Anioł nie powstrzymywał się od wykorzystywania formy krzyża widlastego, jeśli uznał to za stosowne (il. 13)78.

Pierwszym „nieprawdziwym” przedstawieniem, które pochłonęła owa otchłań, była najpewniej Msza św. Grzegorza. Od niebywałej wręcz popularności w XV i wczesnym XVI wieku, straciła swe znaczenie i stała się zbędna około 1550 roku. Teologowie nie sprzeciwiali się temu. Umarła, gdyż zdano sobie sprawę, że istnienie tego zdarzenia nie było wspierane przez generalnie akceptowaną legendę. Wcześni biografowie papieża nie donoszą, iżby postać Chrystusa miała objawić się Grzegorzowi Wielkiemu, ale w XIV wieku wierzono, że obraz Ukrzyżowanego ukazał się papieżowi, gdy ten celebrował mszę w Sta. Prisca ${ }^{79}$. Nie jest znane żadne artystyczne, współczesne temu wydarzeniu, przedstawienie tej sceny i możemy powątpiewać, czy legenda ta kiedykolwiek zakorzeniła się głęboko. Molanus (III,9) znał

14. Mistrz z Flémalle, Trójca Św., ok. 1430, Staedel Institut, Franfurt a.M.

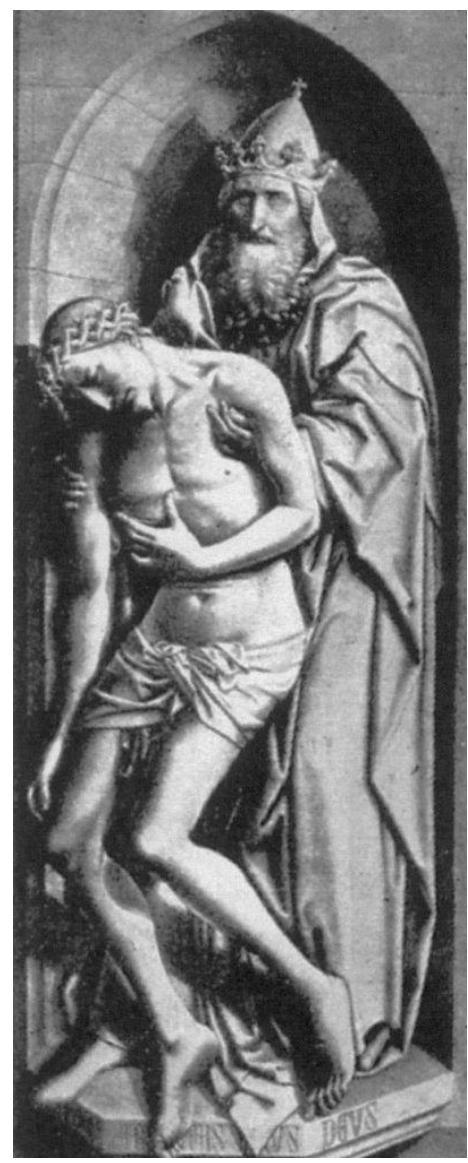

78 Trafną listę dzieł znajdziemy u H. Thode, Michelangelo, T. 3, 2, Berlin 1912, s. 682.

${ }^{79}$ Mirabiliae Romae; wyd. Party, Berlin 1869, s. 61. 
pewną wersję, bardzo popularną we współczesnym mu Rzymie, wedle której papieżowi miał pojawić się Imago pietatis, zwany teraz Gregoriańskim Mężem Boleści. W swej wersji Molanus ustalił źródło inspiracji artysty $^{80}$. Istnieją przedstawienia Mszy św. Grzegorza ukazujące Pana w różnych formach, pojawiającego się w pojedynkę, a istnieją i takie, które nie pokazują Go w ogóle ${ }^{81}$. Jednakże najwcześniejsze znane przedstawienia pochodzące z około 1400 roku ukazują nieskróconą wersję - Chrystus pośród swoich Arma ${ }^{82}$. Odpowiadająca im legenda uformowała się mniej więcej w tym samym czasie w opactwie benedyktyńskim Andechs, nieopodal Monachium ${ }^{83}$. To prawdopodobnie tam, pomiędzy 1389 a 1393 rokiem, legat papieski w Niemczech, Jan z Gubbio, poznał tę legendę i połączył ją z rzymskimi tradycjami ${ }^{84}$. Według niego, cud miał miejsce podczas mszy odprawianej na cześć składającej wizytę królowej hiszpańskiej w kościele St. Croce w Rzymie.

Nie można jak dotąd dowieść, że legenda z Andechs wywiedziona została z przedstawienia obrazowego. Można jednak przyjąć, że źródło obrazów nie leżało w tej tradycji. Nawet jeśli żaden $\mathrm{z}$ nich nie został stworzony przed 1395 rokiem, mało prawdopodobnym jest, że legenda mogła rozprzestrzenić się tak szybko do tak różnych regionów, jak Francja i Gryzonia, bez pozostawienia żadnych śladów w źródłach pisanych. Dowody wskazują na francuskiego pomysłodawcę nowych tematów artystycznych. Sądzę, że porównanie Arma Christi (il. 15) z Msza św. Grzegorza (il. 16) pomoże nam zrozumieć, co tak naprawdę się wydarzyło. W mojej opinii nie ma większego znaczenia fakt, że pierwszy z obrazów powstał około 1350 roku, podczas gdy drugi około 1510 . Często rozwinięta postać trendu czyni go o wiele bardziej wyraźnym i wyczuwalnym niż jego faza wstępna. Co takiego stało się, że artyści zapragnęli dać wizualne

80 Taka geneza jest powszechnie akceptowana. Por. np. E. Mâle, L’art religieux de la fin du moyen âge en France, Paryż 1908, s. 91 i n. J.A. Enders w: Zeitschrift für christliche Kunst, 30, 1917, s. 146 i n., Künstle, op. cit., s. 486 i n. Wartość wszystkich dyskusji, jakkolwiek kompetentni i merytoryczni byliby ich autorzy, jest upośledzona przez błędne założenie jednego definitywnego tematu dla wszystkich przedstawień. Nawet ojciec Josef Braun, Der Christliche Altar, Monachium 1924, s. 453 i n., przyjął to założenie.

${ }^{81} \mathrm{~Np}$. Brit. Libr. Add. Ms. 11866 (c. 1500) fol. 156 vo.

82 Cod. Vindob. 1840 („Kunst und Kunsthandwerk”, 5, 1902, s. 303. B. Martens, Meister Francke, Hamburg 1929, przypis 260); ms. lat. par. 18026 (Mâle, op. cit., s. 94). Zamek Rhaezuens (R. Borrmann, Aufnahmen mittelalterlicher Wand- und Deckenmalereien in Deutschland. I. 1)

83 R. Bauerreiß, w: „Studien und Mitteilungen zur Geschichte des BenediktinerOrdens”, 44, 1926, s. 75; 47, 1929, s. 66. Zadatował wpis w kolumnie 3005: „początek XIV wieku”. A. Brackmann, w: „Abhandlungen der preuß. Akad. der Wissenschaften”, 1929, Nr 5, s. 5, jest, w mojej opinii, trafnie datowany na „ok. 1400”.

${ }^{84}$ Bauerreiß, op. cit., 44, s. 75 i n. Brackmann, op. cit., s. 24 i n. 


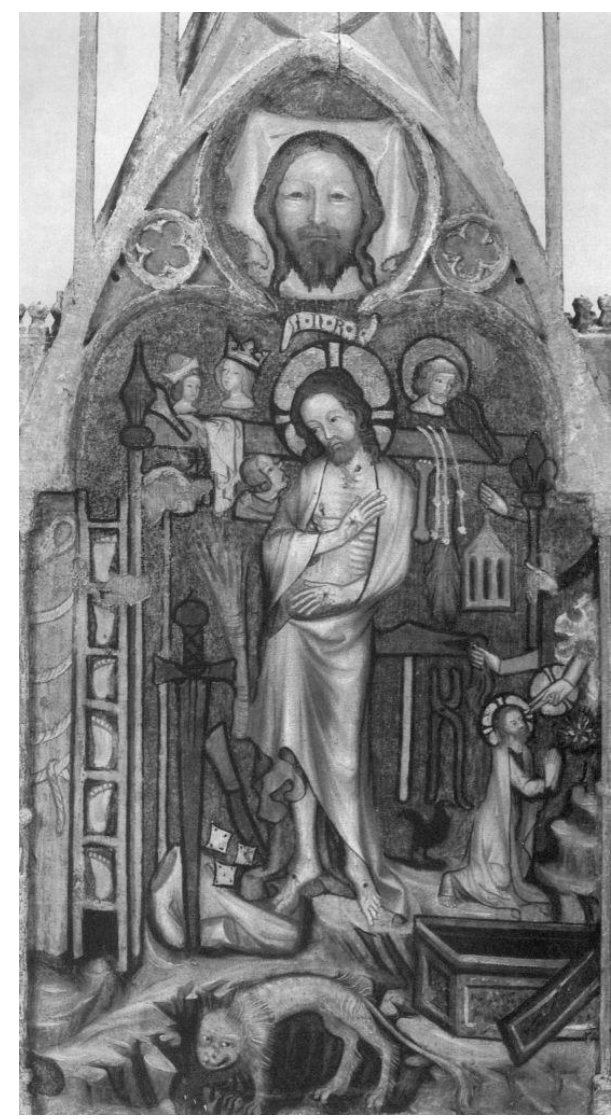

15. Arma Christi, Norymberga, ok. 1350, Germanisches National Museum, Norymberga

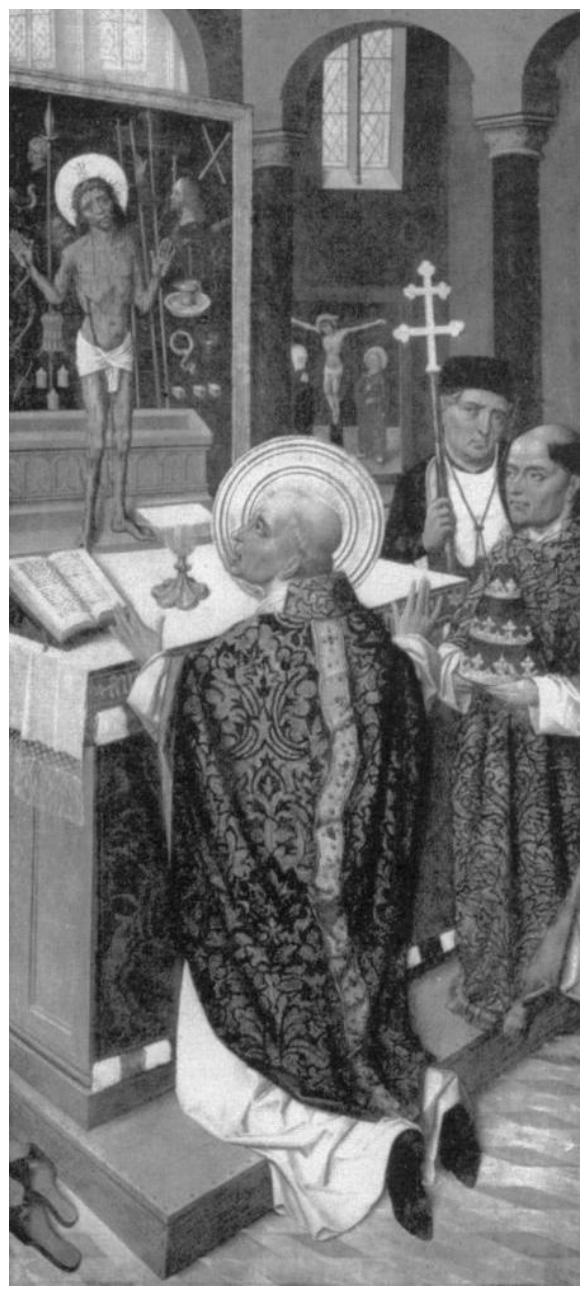

16. Msza św. Grzegorza, Nadrenia, ok. 1500, Galeria, Augsburg

wyjaśnienie nagromadzenia Narzędzi Męki. Jakież wyjaśnienie mogłoby być właściwsze, niż manifestacja nadprzyrodzonego? Obraz z Augsburga jest reprezentatywny dla ostatniej fazy rozwoju i choć przedstawia Arma Christi, to jedynie dla samego Chrystusa rezerwuje cudowne zjawienie. Charakterystycznym jest dla wielu przedstawień, że kładą nacisk na niezdolność papieża do oglądania wizji. Przedstawienia te są w rzeczywistości obrazami transcendentalnego powtórzenia Ofiary podczas mszy. W Hiszpanii nawet przedstawienie Sądu Ostatecznego mogło być połączone z papieską mszą - wizualizacja wagi i znaczenia mszy jako takiej, 
bez wyraźnego połączenia $\mathrm{z}$ jakimkolwiek zdarzeniem wspomnianym $\mathrm{w}$ biografiach papieża ${ }^{85}$. Z drugiej strony istnieje wiele przedstawien, gdzie twarz Chrystusa objawiła się już po końcu mszy ${ }^{86}$. Dla innych temat polegał na oddaniu czci Ofierze, nie przedstawieniu konkretnej mszy lub cudownemu pojawieniu się Arma Christi ${ }^{87}$. Faktem jest, że temat Mszy św. Grzegorza nigdy nie podlegał żadnemu ściśle zdefiniowanemu modelowi przedstawieniowemu. Istniała zawsze obszerna przestrzeń do subiektywnych upodobań. Oddawanie czci zbawieniu oraz uzyskanie odpustów były istotne dla modlących się przed obrazem. Konkretne detale mogły być pozostawione artystom. Do dziś nikt nie potrafił przekonująco wyjaśnić, dlaczego Grzegorz Wielki został wybrany i włączony do tego przedstawienia $^{88}$. Ja również nie potrafię tego wyjaśnić. Fakty wydają się wskazywać, że u jego początków leżał samodzielny wybór jakiejś jednostki.

Wciąż jednak, dwa wieki po Soborze Trydenckim, od katolickiej sztuki religijnej nie zawsze domagano się ewidentnej ortodoksyjności. W przeciwnym wypadku papież Benedykt XIV (1740-1758), który był wrogiem wolności w sztuce poza ustaleniami Soboru Trydenckiego, nie zaakceptowałby przedstawień Trójcy ukazujących Chrystusa martwego (il. 14). Podstawą aprobaty papieża była ich zgodność z zasadą, że Bóg powinien być przedstawiany tak, jak widziany jest ludzkimi oczami ${ }^{89}$. Lecz od strony wizualnej, przedstawienia te stoją w sprzeczności z dogmatycznie właściwym przekonaniem i wprowadzają w błąd. Nigdy bowiem żadna z Osób w Trójcy Jedynego Boga nie powinna być uznana za martwą. Motyw ten, stworzony jako narzędzie obrazowe do pobudzania emocji, lecz obojętny na właściwe symbolizowanie rzeczywistości, został usankcjonowany z przyczyn czysto prawnych dopiero w 1745 roku.

Przełożyt Filip Merski

85 C.R. Post, History of Spanish Painting, T. 4, 2 (1935), il. 179 i n.

${ }^{86} \mathrm{~Np}$. w Westfalii; zob. Bau- und Kunstdenkmäler Westfalens. Kreis Ahaus, il. 16. Kreis Coesfels, il. 65. Kreis Steinfurt, il. 60,5.

87 Np. Mâle, op. cit., il. 37.

${ }^{88}$ Nieco dokładniej zająłem się problematyką Arma Christi w rozprawie, która oczekuje na publikację. Ale następujący fakt powinien być tutaj wspomniany, w szczególności w odniesieniu do ostatniej części niniejszego artykułu. Legenda ukazania się Imago pietatis stoi $\mathrm{w}$ sprzeczności z fundamentalnymi naukami teologicznymi, wedle których żadne cudowne objawienie nie ukazywało Chrystusa martwym; por. Molanus IV, 16, lub świadectwo, które było współczesne z tworzeniem obrazu: Frater Henricus Institor, Tractatus novus de (...) sacramento, Augsburg 1493, fol. A, II v. Papież Benedykt XIV nie odrzucił tej doktryny.

${ }^{89}$ Benedicti Papae XIV (...) Bullarium, vol. I, Rzym 1746, s. 567 i n. Napisałem ten artykuł w języku niemieckim w 1937 roku i chciałbym wyrazić swoją wdzięczność za ogromną pomoc wielu tym, którzy uczestniczyli w przygotowaniach tej publikacji. 